NBER WORKING PAPER SERIES

\title{
PROJECTING BEHAVIORAL RESPONSES TO THE NEXT GENERATION OF RETIREMENT POLICIES
}

\author{
Alan L. Gustman \\ Thomas Steinmeier \\ Working Paper 12958 \\ http://www.nber.org/papers/w12958
NATIONAL BUREAU OF ECONOMIC RESEARCH
1050 Massachusetts Avenue
Cambridge, MA 02138
March 2007

The research reported herein was conducted pursuant to grants UM03-03, UM04-01, and UM05-02, from the U.S. Social Security Administration (SSA) to the Michigan Retirement Research Center (MRRC), with subcontracts to the National Bureau of Economic Research. The findings and conclusions expressed are solely those of the authors and do not represent the views of SSA, any agency of the Federal Government, the MRRC or the NBER. The views expressed herein are those of the author(s) and do not necessarily reflect the views of the National Bureau of Economic Research.

(C) 2007 by Alan L. Gustman and Thomas Steinmeier. All rights reserved. Short sections of text, not to exceed two paragraphs, may be quoted without explicit permission provided that full credit, including (C) notice, is given to the source. 
Projecting Behavioral Responses to the Next Generation of Retirement Policies

Alan L. Gustman and Thomas Steinmeier

NBER Working Paper No. 12958

March 2007

JEL No. D31,D91,E21,H55,I3,J08,J14,J26,J32,J38

\begin{abstract}
$\underline{\text { ABSTRACT }}$
This paper examines retirement and related behavioral responses to policies that on average are actuarially neutral. Many conventional models predict that actuarially neutral policies will not affect retirement behavior. In contrast, our model allows those with high time preference rates to find that the promise of an actuarially fair increase in future rewards does not balance the loss from foregone current benefits. Using data from the Health and Retirement Study, we find that from age 62 through full retirement age, the earnings test reduces full-time work by married men by about four percentage points, or by about ten percent of married men at full-time work. Abolishing the requirements on many jobs that an individual work full-time or not at all, what we term a minimum hours constraint on employment, would induce more than twice as many people to enter partial retirement as would leave full-time work, so that total full-time equivalent (FTE) employment would increase, although by a modest amount. If all benefits from personal accounts could be taken as a lump sum, the fraction not retired at age 62 would fall by about 5 percentage points compared to a system where there is mandatory annuitization of benefits.
\end{abstract}

\author{
Alan L. Gustman \\ Department of Economics \\ Dartmouth College \\ Hanover, NH 03755-3514 \\ and NBER
}

ALAN.L.GUSTMAN@DARTMOUTH.EDU

Thomas Steinmeier

Department of Economics

Texas Tech University

Lubbock, TX 79409

thomas.steinmeier@ttu.edu 
Until the 1980s, both the federal government and employer policies encouraged workers to retire by age 65 . Employers were free to mandate retirement by age 65, and many did. In addition, the dominant type of pension plan, the defined benefit plan, often stopped crediting work at age 65. When a person worked an additional year, one year's pension was lost, but future pension payments were not increased to compensate. Similarly with Social Security, when a person worked after age 65 and lost benefits to the retirement test, future Social Security benefits were not increased by an amount that would compensate for the lost benefits. Other features of pensions, including availability of early benefits, and supplements to pensions taken at early ages, encouraged even earlier retirement.

However, with the baby boomers approaching retirement age, in the past few decades both the government and employers have done an about face. They not only eliminated policies that encouraged retirement by age 65 or earlier, but adopting policies to encourage older persons to delay their retirements. Some of these policies, such as the 1983 Social Security reforms, increase adjustments in future benefits to compensate for benefit payments lost to the earnings test, or to otherwise compensate when benefit claiming is delayed. Other public policies encourage later retirement by outlawing age discrimination, mandatory retirement, and by requiring that pension benefits give credit for work after normal retirement age, or that they are otherwise adjusted on an actuarially fair basis. ${ }^{1}$ The trend from defined benefit to defined contribution plans and the adoption of hybrid plans also encourage delayed retirement. ${ }^{2}$ Today, benefit structures in pensions and Social Security are now roughly actuarially fair, in that

\footnotetext{
${ }^{1}$ The 1983 Social Security reforms significantly increased the incentive to postpone retirement after age 65 . Among other things, the delayed retirement credit was gradually increased from 3 percent to 8 percent, and the normal retirement age was raised. Subsequently, the earnings test was abolished for those over the normal retirement age. Age discrimination rules abolished mandatory retirement at age 65 for most jobs, and eliminated certain (but not all) actuarial penalties found in defined benefit pensions that effectively reduced the reward to work after age 65 .

${ }^{2}$ Anderson, Gustman and Steinmeier (1999) quantify the effects on retirement of changes in Social Security rules, abolition of mandatory retirement, changes in defined benefit structures and substitution of DC for DB plans. See also Friedberg and Webb (2003).
} 
disincentives from inadequate benefit accrual rates for those who postpone retirement have been eliminated.

Now a new generation of retirement policies is under consideration. Although actuarially neutral, these policies are likely to affect retirement outcomes. One such policy follows on the elimination of the Social Security earnings test for those over normal retirement age, and would eliminate the earnings test between early and normal retirement age. Another of these policies would increase the ages of benefit entitlement. Still another such policy emerges from a central focus of the past few years on the adoption of personal accounts. Although Social Security benefits are currently paid in the form of an annuity, benefits from either defined benefit plans or from personal accounts may be made available as an annuity or as a lump sum of equivalent actuarial value. A related policy choice between actuarially equivalent benefits emerges on the pension side. There has been discussion of relaxing current IRS prohibition against paying a pension benefit when a person remains at work, instead allowing partial pension benefits to be paid to those who partially retire on a job.

Unfortunately, when it comes to distinguishing between these and other policies offering choices between actuarially equivalent outcomes, many of the tools that have been used to analyze the effects of retirement policies on retirement behavior either fall silent, or suggest counter to their likely effects that these policies will have no impact on retirements. In particular, a central feature of many retirement equations is the pension or Social Security delta, the change in present value of benefits with continued work. In the case of actuarially fair policies, these deltas are zero, so the prediction is that the policies will have no effect on retirement. 
This paper examines the effects on retirement of certain proposals that are part of the new generation of actuarially neutral policies. As we show, contrary to predictions from simple retirement equations, these policies will nevertheless affect retirement, primarily as a result of a mismatch between certain person's rate of time preference and the discount rate implicit in the design of the pension or Social Security. Consider some of the policies noted above. Although the earnings test taxes away benefits from earnings above the disregard amount, subsequent yearly benefits are increased to compensate for benefits lost. Compensation carries an implicit interest rate specified in the law. However, among those with high time preference rates, that interest rate is not adequate. Under current law they are not adequately compensated for postponing retirement, so they don't. Once the earnings test is abolished, in this case between the early and normal retirement age, they are no longer subject to inadequate compensation for postponing retirement, and therefore they may delay their retirement. Similarly, allowing benefits from pensions or Social Security to be paid as a lump sum encourages those with high time preference rates to accelerate their retirement. Those with high time preference rates and consequently little saving will prefer a lump sum settlement, even though the annuities are actuarially equivalent in value. Increasing the age of eligibility for benefits will reduce retirements as those with high time preference rates who retire to avoid waiting for benefits under the current system will instead find postponing retirement no longer reduces their Social Security benefits while still at work (Gustman and Steinmeier, 2005a).

Of course, these substitution effects will not always dominate. If there are wealth effects, or assets become available at particular ages to a person who is liquidity constrained, these effects must also be considered. Once again, most retirement equations will fall silent, especially about any liquidity effects. 
A key to analyzing this next generation of policy initiatives is to incorporate differences in time preference rates into the underlying behavioral model of retirement. To do that, one must relax the assumption of perfectly operating capital markets and consider the joint determination of retirement and saving. As long as one cannot borrow extensively on the basis of future pension and Social Security payments, those with different time preference rates may have different valuations for benefits received at different times, even if the benefits are actuarially equivalent, e.g., for lump sum vs. an annuity or other deferred payouts. This type of distinction is not included in the first generation of retirement models.

We will estimate and apply an extended version of a model developed in Gustman and Steinmeier (2005a) to analyze the retirement implications of these newer policies. Outcomes analyzed in the model we estimate include the decisions to fully or partially retire, to save, to claim benefits, to participate in personal accounts, the choice of whether to take benefits as an annuity or lump sum, and the course of benefit and tax payouts.

Section II discusses our retirement model and its estimation. Section III analyzes the likely effects of abolishing the retirement earnings test between early and normal retirement age, and compares the effect of abolishing the earnings test with the policy of raising the Social Security early entitlement age. We then turn in Section IV to an analysis of the differential effects on retirement of actuarially equivalent lump sum and annuity payouts to systems of personal accounts, as well as the effects of adopting various structural components of personal account schemes. Section V changes the focus somewhat and asks about the changes in behavioral outcomes that may result from the adoption by firms and the IRS of policies that would permit flexible retirement on most jobs where minimum hours constraints and pension rules now prohibit them. 


\section{A. The retirement model.}

The model estimated here jointly explains retirement and saving, and allows for heterogeneity in both time preference and in tastes for leisure. In the basic model, the individual is assumed to maximize a utility function of consumption and leisure over time. The constraints include an asset accumulation equation and an uncertain lifetime. ${ }^{3}$

This model extends in a number of directions a structural, dynamic model of retirement and saving that we have developed in previous work (Gustman and Steinmeier, 2005a and b). One extension allows individuals to choose optimally when to register for Social Security benefits. Another extension more systematically specifies the role of minimum hours constraints. A third modification introduces the value of employer provided health insurance into compensation, while allowing the value of own and spouse insurance to go to zero at age 65 as the relevant covered person becomes eligible for Medicare.

In this paper, retirement is not, however, modeled stochastically. The two paths open are full-time work to full-retirement, and full-time work to partial retirement to full retirement. There are no reversals from states of lesser to states of greater work. For a similar model that includes reversals from full-retirement to full-time work, but does not allow partial retirement, see Gustman and Steinmeier (2002).

${ }^{3}$ Structural models in the spirit of the present model, where capital markets are not operating perfectly, have been estimated by Rust and Phalen (1997), French (2005), van der Klaauw and Wolpin (2006) and Bound, Stinebrickner and Waidmann (2006). These models have different purposes than the one we estimate here, and develop those aspects of the model that are aimed at the question at hand in greater detail than we do. However, given their different emphases, each assumes away one or another feature that is central to the present analysis, simplifying the representation of incentives from defined benefit pensions, ability to borrow, joint determination of saving and retirement, or inclusion of partial retirement, among others. None of these models fully analyzes joint decision making within the household. Our model takes the labor market decision of the spouse as exogenous. For models of joint decision making by couples, which simplify other dimensions of retirement and retirement decision making in comparison to the present model, see Gustman and Steinmeier (2004) and Blau and Gilleskie (2006). 
Utility. In the model, the individual is assumed to maximize a utility function of consumption and leisure over time:

$$
U=\sum_{t=0}^{T}\left\{e^{-\rho t} \sum_{m=1}^{3}\left[S_{m, t}\left(\frac{1}{\alpha} C_{m, t}^{\alpha}+e^{X_{t} \beta+\varepsilon} \frac{1}{\gamma} L_{m, t}^{\gamma}\right)\right]\right\} \quad \alpha, \gamma<1
$$

In this equation, $\mathrm{T}$ is the maximum lifespan and $\mathrm{m}$ refers to the family structure at time $\mathrm{t}$ (both spouses alive, only the husband alive, or only the wife alive). $\mathrm{s}_{\mathrm{m}, \mathrm{t}}$ is the probability of family structure $\mathrm{m}$ at time $\mathrm{t}, \mathrm{C}$ is consumption, and $\mathrm{L}$ is the leisure, which takes on a value of 0 for full-time work, 1 for full retirement, and $1 / 2$ for partial retirement, assuming that partial retirement involves half time work. ${ }^{4} \mathrm{X}$ includes a constant, age, health status, and vintage. The age variable in $\mathrm{X}$ causes leisure to become gradually more attractive as the individual ages, reflecting the gradual wear and tear that makes the rigors of work relatively less attractive. As the value of leisure increases for this reason and perhaps also because of worsening health, at some point the utility of leisure surpasses the utility of the consumption that continued work makes possible, and the individual retires. It is important to note explicitly that $\mathrm{X}$ does not contain any binary age variables or splines in age which might encourage retirement at a particular age.

Heterogeneous Elements of Utility. These preferences allow for three types of heterogeneity. The time preference term $\rho$ is a fixed effect, and the leisure preference term $\varepsilon$ is a random effect drawn from a normal distribution. The parameter $\gamma$, which governs how desirable partial retirement is relative to full retirement or full-time work, is also a random effect. It is taken so that the term $(1 / 2)^{\gamma}$ comes from the exponential distribution $\mathrm{f}\left[(1 / 2)^{\gamma}\right]=\mathrm{ke}^{\delta(1 / 2)^{\gamma}}$

\footnotetext{
${ }^{4}$ In recognition that consumption is more valuable while both spouses are alive, the consumption function is adjusted so that the marginal utility for a surviving spouse is approximately equal to that for a couple consuming $40 \%$ more.
} 
defined over $(1 / 2)^{\gamma} \in[1 / 2,1]$, which is the theoretically acceptable range of $(1 / 2)^{\gamma}$ for $\gamma \in[0,1]$. $\mathrm{k}$ is the constant necessary for the density function to integrate to unity, as it must. If $\gamma$ is close to unity, then full-time leisure has about half the value of half-time leisure, and the individual regards the utility of an hour of leisure (and the disutility of an hour of work) as about the same regardless of whether the work is full-time or part-time. If $\gamma$ is close to zero, then part-time leisure is almost as valuable as full-time leisure. In this case, the individual does not mind parttime work too much but really dislikes having to work full-time. Since partial retirement seems to become relatively more attractive as the individuals age, we specify $\delta$ to be increasing in age: $\delta=\delta_{\mathrm{o}}+\delta_{\mathrm{a}} \times$ Age

The Budget Constraint. The asset accumulation over time is given by

$$
A_{m, t}=(1+r) A_{k, t-1}+W_{m, t}\left(1-L_{m, t}\right)+E_{m, t}+B_{m, t}-C_{m, t}, \quad \text { with } A_{m, t} \geq 0
$$

where $A_{m, t}$ is the level of real assets at time $t$ in survival state $m, r$ is the real interest rate, $\mathrm{W}_{\mathrm{m}, \mathrm{t}}$ is the real wage rate, $\mathrm{E}_{\mathrm{m}, \mathrm{t}}$ is the earnings of the spouse, and $\mathrm{B}_{\mathrm{m}, \mathrm{t}}$ is the level of Social Security and/or pension benefits at time t. The equation must hold for any legitimate transition between survival state $\mathrm{k}$ at time $\mathrm{t}-1$ and survival state $\mathrm{m}$ at time $\mathrm{t}$. If the individual is working, the wage rate may depend on whether the work is full-time or part-time. Workers are allowed to partially retire, usually in different jobs from those held in prime working age. Work when partially retired on a new job reduces firm specific human capital to zero, and may involve relaxation of other job requirements. As a result, partial retirement on a job not held during prime working years typically pays a lower wage rate (Gustman and Steinmeier, 1983, 1985). Social Security enters as income in the asset accumulation equation in the years that benefits are received. We also include the effects of health insurance on retirement, expecting the effect to be most observable at age 65 . Specifically, we include an estimate of the value of employer 
provided health insurance in the budget constraint, but note that the net value of this insurance declines at age 65 when a person who is not employed becomes eligible for Medicare as the primary payer. The earnings and pension benefits of the spouse are treated as exogenous in this paper.

The level of benefits $B_{m, t}$ at time $t$ depends on the previous decisions of the individual as to when to leave full-time employment and when to retire fully, as well as the current survival state. Note that this model does not calculate the value of accruals to Social Security and pensions directly, but the value of the accruals is implicit in the model because work during one period will affect the value of Social Security and pension benefits in later periods. The implicit value of these accruals, of course, depends strongly on the time preference rate. It also depends on the decision of the individual as to when to apply for Social Security benefits; obviously, no benefits can be paid until the individual has applied for them. This means that a delay in the application will result in increased benefits later.

\section{B. Estimation.}

Estimation is based on the general method of simulated moments. ${ }^{5}$ The calculation of the simulated moments follows from the following decomposition of the utility function:

$$
\mathrm{U}=\left[\sum_{\mathrm{t}=0}^{\mathrm{T}} \sum_{\mathrm{m}=1}^{3}\left(\mathrm{e}^{-\rho \mathrm{t}} \mathbf{s}_{\mathrm{m}, \mathrm{t}} \frac{1}{\alpha} \mathrm{C}_{\mathrm{m}, \mathrm{t}}^{\alpha}\right)\right]+\left[\sum_{\mathrm{t}=0}^{\mathrm{T}} \sum_{\mathrm{m}=1}^{3}\left(\mathrm{e}^{-\rho \mathrm{t}} \mathrm{s}_{\mathrm{m}, \mathrm{t}} \mathrm{e}^{\mathrm{X}_{\mathrm{t}} \beta} \frac{1}{\gamma} \mathrm{L}_{\mathrm{m}, \mathrm{t}}^{\gamma}\right)\right] \mathrm{e}^{\varepsilon}
$$

A crucial observation is that the first part of the utility function does not depend on the random effects $\varepsilon$ and $\gamma$, and the second part does not depend on consumption or the budget set. For all possible combinations of partial and full retirement ages, and for all possible ages for initial Social Security claims, the budget set is calculated. Given the budget set, and given values of $\alpha$ and $\rho$, optimal consumption is calculated by solving the dynamic programming model. The

\footnotetext{
${ }^{5}$ For a more detailed description, see Pakes and Pollard (1989), Duffie and Singelton (1993), and Greene (2000).
} 
associated utility of the optimal consumption stream is $U_{C}\left(r_{1}, r_{2}, a ; \alpha, \rho\right)$, where $r_{1}$ is the age of partial retirement, $r_{2}$ is the age of full retirement, and $a$ is the claiming age. If there is no partial retirement, $r_{1}=r_{2}$. The optimal claiming behavior for particular values of $r_{1}$ and $r_{2}$ is just the value of a which maximizes $U_{C}: U_{C}\left(r_{1}, r_{2} ; \alpha, \rho\right)=\max _{a} U_{C}\left(r_{1}, r_{2}, a ; \alpha, \rho\right)$.

Next, 10,000 random values of $\varepsilon$ and $\gamma$ are chosen, and for each set the value of the second part of the utility function is evaluated for each combination of $r_{1}$ and $r_{2}$. This utility depends on the retirement dates and the value of $\beta: U_{L}\left(r_{1}, r_{2} ; \varepsilon, \gamma, \beta, \rho\right)$. Note that the calculation of $\mathrm{U}_{\mathrm{L}}$ does not require the solution of a dynamic programming model and hence can be done quickly. For each set of $\varepsilon$ and $\gamma$, the total utility is evaluated for each set of retirement dates $r_{1}$ and $r_{2}$, and the retirement dates are the ones which maximize the total utility: $\mathrm{U}(\varepsilon, \gamma, \rho ; \alpha, \beta)=\max _{\mathrm{r}_{1}, \mathrm{r}_{2}}\left[\mathrm{U}_{\mathrm{C}}\left(\mathrm{r}_{1}, \mathrm{r}_{2} ; \alpha, \rho\right)+\mathrm{U}_{\mathrm{L}}\left(\mathrm{r}_{1}, \mathrm{r}_{2} ; \varepsilon, \gamma, \beta, \rho\right)\right]$. Thus, given $\rho$ and values for the parameters $\alpha$ and $\beta$, the distribution of retirement ages is built up from the 10,000 values of $\varepsilon$ and $\gamma$.

The next issue is: where do we get the value for the fixed effect $\rho$ ? To resolve this, we use the actual retirement dates (if retirement occurs within the sample) or the individual's reported expected retirement dates (if it does not). Given a value of $\alpha$, we then pick a value of $\rho$ and solve the consumption problem described above. Using the optimal consumption values and the asset accumulation equation, we can solve for assets at the beginning of the sample period, which is 1992 for the HRS. If these assets are larger than the assets actually observed, we adjust $\rho$ upward; otherwise we adjust $\rho$ downward. The fixed effect is the value of $\rho$ for 
which the calculated accumulation just matches the actual assets. ${ }^{6}$ Note that this fixed value depends on the value of $\alpha$ and so must be recalculated each time the estimation procedure considers a new value of $\alpha .^{7}$

For a given set of parameters, these simulations give simulated sample moments. In the generalized method of simulated moments, these simulated sample moments are compared to the actual sample moments, and the procedure adjusts the parameters to minimize the differences between the simulated moments and the actual moments. In the minimization, the moments are weighted so as to provide the most precise estimates possible with the data. The estimation is based on 46 moments. Thirteen of the moments are the percentages working full-time at each age between 54 and 66. The remaining moments are calculated at ages 55, 58, 60, 62 and 65 and include five moments for the percentage fully retired at the indicated ages, the percent of those with a health problem who are working full-time, the percent of those with a health problem who are fully retired, the percent of those born before 1934 who are working full-time, the percent of those born after 1938 who are working full-time, the percent of those with lifetime incomes below $\$ 1,250,000$ who are working full-time, and the percent of those with lifetime incomes above $\$ 1,900,000$ who are working full-time. The income figures and vintages are chosen to divide the sample roughly into thirds. Two moments are lost because those born before 1934 could not have been 55 in the survey time frame, and those born after 1938 could not have reached 65 within this time frame.

The model has 8 parameters to be estimated. These include the consumption parameter

\footnotetext{
${ }^{6}$ This calculation is slightly modified in the cases of extremely high, or zero wealth. When an individual has more assets than would be calculated even at a zero time preference rate, this is taken as a signal of a low time preference rate, and a value of zero for the time preference rate is assigned. An individual who has zero assets, even allowing for a defined contribution lump sum which would be available at retirement, is at a corner solution with regard to assets. Although the time preference rate for such an individual cannot be completely determined, only an individual with a very high time preference rate would have zero assets on the verge of retirement. Such an individual is assigned an arbitrarily high time preference rate, causing each period's income to be fully consumed. ${ }^{7}$ Samwick (1998) uses a similar approach and finds wide heterogeneity in time preference rates.
} 
$\alpha$, four elements of $\beta$ including the constant and coefficients for age, poor health, and birth year, two elements of $\delta$ including a constant and a coefficient of age, and the standard deviation of retirement preferences given by $\sigma_{\varepsilon}$.

The simulations proceed in almost exactly the same manner as the estimates, except that only the estimated values of the parameters need be considered. Tallies can be made for almost any aspect of the model, including the percentages fully retired and partially retired at different ages, the percentage claiming Social Security benefits, the distribution of time preference rates, and the amount of Social Security taxes and benefits by age. Simulations are accomplished by simply making the appropriate changes in the budget sets and simulating the results. Simulations include married men only. The simulations use a real interest rate of 4.31 percent per year as the assumed return on investments in personal accounts. This is the average compounded rate from 1926-2002 of an asset basket of 50 percent large cap stocks, 5 percent long-term bonds (treasury bonds) and 45 percent treasury notes, as measured by Ibbotson Associates (2002).

\section{C. Data used in the model estimation.}

The model is estimated for married men who are career workers from the original cohorts of the Health and Retirement Study, using observations from the first eight waves of the survey, every other year from 1992 through 2004, including restricted Social Security and pension data collected in the initial year of the survey. The selection of the sample, and reasons for deleting observations, are reported in Appendix Table 1.

The definition of retirement in this study is a hybrid one relying both on objective and subjective measures. Individuals working at least 30 hours per week and 1560 hours per year are counted as full-time. Individuals working at least 100 hours per year but no more than 25 hours per week or 1250 hours per year are counted as part-time, and individuals not doing any work at 
all are counted as fully retired. Individuals who fall between full-time and part-time or between part-time and retired are classified on the basis of self reports.

Earnings profiles are taken from Social Security records or, if these are not available, from the retrospective information in the respondent surveys. Future potential earnings are projected on the basis of tenure and experience coefficients of earnings regressions. Pension benefits, conditional on tenure in the job providing the pension, are based on information in the summary pension descriptions, provided by the employers. Social Security benefits are based on the earnings histories and figured according to the Social Security rules.

\section{D. Parameter Estimates}

Table 1 reports parameter estimates. There are 46 moments in the estimation, leaving 38 degrees of freedom. The cutoff points of the chi-squared distribution are 53.15 for 5 percent, so the model is not rejected at the 5\% significance level. The coefficients are of similar magnitudes to those in our earlier estimates. Everything except the vintage coefficient is significant. A key to understanding these results is in the time preference rates. These rates are heterogeneous, with 45 percent of the population exhibiting time preference rates above 5 percent, and one third exhibiting time preference rates of 20 percent or greater. ${ }^{8}$ These rates are consistent with Samwick (1998).

\section{E. Comparison of observed and predicted outcomes.}

As is well known, in recent years, the most prominent spike in retirement occurs around

${ }^{8}$ Distribution of Time Preference Rates
\begin{tabular}{|l|l|l|l|l|l|l|l|}
\hline Rate & No. Obs. & Rate & No. Obs. & Rate & No. Obs. & Rate & No. Obs. \\
\hline $0-.05$ & 474 & $.3-.35$ & 12 & $.6-.65$ & 1 & $.9-.95$ & 1 \\
\hline $.05-.1$ & 759 & $.35-.4$ & 10 & $.65-.7$ & 4 & $.95-1$ & 2 \\
\hline $.1-.15$ & 170 & $.4-.45$ & 4 & $.7-.75$ & 2 & $>1$ & 664 \\
\hline $.15-.2$ & 59 & $.45-.5$ & 8 & $.75-.8$ & 1 & & \\
\hline $.2-.25$ & 29 & $.5-.55$ & 4 & $.8-.85$ & 1 & & \\
\hline $.25-.3$ & 22 & $.55-.6$ & 2 & $.85-.9$ & 2 & & \\
\hline
\end{tabular}


the age of early entitlement to Social Security benefits, age 62. Roughly 15 percent of the relevant sample of males retires at age 62, about 9 percent more than those retiring in surrounding years. About 9 percent of the population retires from full-time work at age 65, about 3.5 percent more than those retiring in neighboring years. Note that these percentages are percentages of the population retiring at different ages, not the hazard rates for retirement at particular ages.

Table 2 reports observed retirement outcomes, and predicted retirement outcomes under the current program, with each included individual having the work history actually experienced, and reflected in own Social Security earnings record and reported job history. An indication of the ability of the model to fit the data can be seen by comparing the baseline simulations of the retirement outcomes at different ages.

The spike in retirements from full-time work at age 62 and 65 are approximately the right height. Comparing the flow into full retirement, the spikes at both 62 and 65 are a couple of points too low. More specifically, comparing the retirement rates from full-time in the baseline simulation results, with the observed retirement rates, the simulations catch the spike in retirements at age 62 , where 14.8 percent of the population is simulated to retire from full-time work, where 15.1 percent actually retire at age 62 . At 65 the actual spike in retirements from full-time work is 9.1 percent, while the simulations generate a peak of 6 percent. With regard to the numbers completely retiring from the labor force, the simulations catch 10.3 percent out of the 12.5 percent found to retire in the raw data at age 62 , and 5.3 percent out of 6.7 percent at age 65.

One reason for the accelerated flow of retirements at 65 should be noted. As indicated earlier, most pension plans and Social Security are now actuarially fair. Health insurance may 
affect the flows into retirement. Specifically, the availability of Medicare at age 65 reduces the value of employer provided health insurance after that age. At 65 , there essentially is a reduction in the wage of an employed person with health insurance. It is important to recognize that the influence of health insurance does not reflect the effect of health insurance coverage per se. Those who are sufficiently well informed could obtain Cobra coverage at age 63.5 that would last until they became eligible for Medicare. So if the absence of coverage were the key determinant of retirement, instead of the net wage, and if workers were sufficiently well informed about COBRA, there would be a secondary spike in retirement at age 63.5, rather than at age $65 .{ }^{9}$

Table 3 presents descriptive statistics on benefit claiming by age and Table 4 presents the simulated values obtained from the model. The model tracks the fraction of the population claiming Social Security benefits between ages 62 and 65 fairly well, understating claiming behavior on average by a modest amount, and missing the mark most severely at age 63 . According to the last column of Table 3, 47.5 percent of all married men claim their benefits at age 62. The last column of Table 4 projects a claiming rate of 41.3 percent at age 62 . While the claiming rate at age 62 is affected by the fact that it is a transition year (see Olson, 1999), the projected claiming rate for the full sample at age 63 is 48.1 percent, compared to an actual claiming rate of 61.7 percent. For ages 64 and 65, the claiming rates are 68.4 and 84.6 percent, while the projected claiming rates are 60.1 percent at age 64 , and 84.7 percent at age 65 . Again it is at age 63 that the projected claiming behavior falls furthest below the mark.

Tables 3 and 4 also project the claiming rate conditional on retirement status. For

\footnotetext{
${ }^{9} \mathrm{We}$ have investigated the role of employer provided retiree health insurance and found that role to be minor. This finding has been supported in the work of Blau and Gilleskie (2006) and others.
} 
example, from Table 3, first column, the actual claiming rates for those who have left full-time work are 72.0, 83.7 and 86.1 percent for those 62,63 and 64 respectively, while from the first column in Table 4, the projections are 59.9, 65.1 and 77.1 percent respectively.

\section{Abolishing the retirement earnings test between early and normal retirement age.}

The Senior Citizens Freedom to Work Act of 2000 (PL 106-182) abolished the Social

Security earnings test for those between the full retirement age and 70 years of age. ${ }^{10}$ It is expected that abolishing the earnings test for those between the early and full retirement age would further encourage later retirement. ${ }^{11}$ This is despite the fact that postponing benefits results in increases in future benefits that are, for many individuals, better than actuarially fair. ${ }^{12}$

\section{IIIA. Overview of the earnings test issue.}

To understand the effects of abolishing the earnings test for those between 62 and the normal retirement age, one must understand not only how retirement responds to the immediate reward for work against the benefit payments that would be received should the person retire, but how different people in the population value the increased benefit payments in future years that are paid when one postpones retirement. The valuation of the tradeoff between current and future benefit payments may not be determined by the market interest rate alone. As we have seen in the discussion of the retirement model above, a person with a high rate of time preference

\footnotetext{
${ }^{10}$ Under current Social Security law, benefits are reduced for each year one claims benefits before the full retirement age. This means that for every year benefits are not claimed after age 62, future benefits are adjusted upward. For example, a person born by January 1, 1938, who has a full retirement age of 65 , would receive 80 percent of full benefits upon retiring at age 62 . Therefore, postponing benefit receipt until age 63 would increase yearly benefits by 8.38 percent (.067/.8) for the rest of his life. The earnings test has a similar effect. For those between ages entitling them to early and full benefits, the Social Security earnings test reduces benefits received by fifty cents for every dollar earned over the exempt amount (\$11,520 in 2003). A person expecting a yearly Social Security pension of $\$ 10,000$ at age 62 would find the entire benefit reduced to zero if earnings reached $\$ 31,520$. Benefits lost to the earnings test are restored in future years, again at a rate that for many is better than on an actuarially fair basis.

${ }^{11}$ For those born in 1937 or earlier, who attained age 62 by 1999, the full retirement age is 65 . The full retirement age is then increased two months per year until reaching 66 for those born in 1943, staying at 66 between 1943 and 1954, and increasing in two month increments per year of birth between 1955 and 1960, where it reaches age 67.

${ }^{12}$ At a 3 percent real interest rate, and for many taking into account the effect of postponing own benefits on benefits paid to their spouse, given current life tables this adjustment is better than actuarially fair (Gordon and Blinder, 1980; Feldstein and Samwick, 1992).
} 
and no ability to borrow at the lower rate said to obtain in the market will discount future benefit adjustments more heavily than the market rate suggests. ${ }^{13}$

Heterogeneity in time preference rates may help to explain the prevalence of benefit claiming at the early entitlement age, a phenomenon that researchers have had difficulty explaining (Coile et al., 2002). ${ }^{14}$ Although policy analysts are well aware of the relation of the earnings test to the timing of benefit claiming (Gruber and Orzag, 1999), empirical studies of the role of the earnings test have not focused on its implications for the timing of benefit claiming. Rather, much of the discussion of the earnings test has focused on the labor market behavior of those who are collecting benefits. In particular, it has long been recognized that many people who are collecting Social Security benefits, but who work part-time, stop working when their earnings just reach the annual exempt amount (Gordon and Blinder, 1980; Burtless and Moffitt, 1984).

Abolishing the earnings test is simulated by allowing immediate benefit claiming between the early and full retirement age without reducing benefits in accordance with a person's earnings. For those who have a high discount rate, there will be an interaction between the earnings test, benefit claiming and retirement. Because benefits can be claimed immediately, the opportunity cost of continued work is reduced. Before the abolition of the earnings test, the current benefit is lost, and the increase in future benefits is inadequate to compensate, so the individual with a high discount rate may choose to retire. After the earnings test is abolished, the same individual will be able to continue at work without having to forego the benefit payment,

\footnotetext{
${ }^{13}$ Studies of the effects of abolishing the earnings test rely either on changes in the earnings test kink point (Friedberg, 2000), or on the observed change in employment patterns between workers affected by the abolition of the earnings test and those who are not. Disney and Smith (2002) examine the effects of the abolition of the earnings test in Britain. Song (2002), Song and Manchester (2006) and Tran (2002) examine the effects of abolishing the earnings test for those over the normal retirement age in the U.S.

${ }^{14}$ Friedberg (2000) produces a reduced form analysis of the retirement earnings test. Her analysis falls silent on the question of benefit acceptance and the wide distributions of time preferences that characterize the population.
} 
and so may choose to stay at work. The resulting changes in full-time and part-time work among other things depend on the distributions of time and leisure preference, as well as the opportunity set, all of which are estimated by the model.

\section{B. Descriptive data on the earnings test and benefit claiming.}

Table 5 shows that data from the 1992-2004 waves of the Health and Retirement Study (HRS) duplicate the findings from earlier studies regarding the bunching of work effort around the earnings test limit. For example, consider those who are partially retired. As seen in the middle panel, grouping partially retired respondents by their earning bracket, and using brackets defined in ten percentage point intervals, the brackets from 50 percent to 100 percent of the earnings test amount each contains roughtly 7 percent to 9 percent of the 62 to 69 year olds in the survey. Each bracket from 110 percent to 150 percent of the earnings test amount contains 1 percent to 3 percent of the population.

In the year 2000 the earnings test was abolished for those over age 65, and it should be possible to see if this had any effect on work. Table 6 presents data for full-time work by HRS respondents in the survey years 1996, 1998, 2000, and 2002. Since 2000 was the year the earnings test was abolished, and there was some confusion in that year, we can compare 2002, after the test was abolished, with 1998, before the test was abolished. The next to the last column calculates the difference in the percentages between 2002 and 1998. For instance, 32.7\% of 62 year olds were working in 2002, compared to $29.4 \%$ in 1998, for an increase of 3.3 percentage points. For 65-67 year olds, for whom the test was abolished, the increase in fulltime work was 3.1 percentage points, while for 62-64 year olds, for whom the test remained in effect, the increase in full-time work was 2.8 percentage points. By this metric, it appears that abolishing the test for those over 65 did not have much of an effect, since they behaved very 
similarly to those under 65 , for whom the test was not abolished.

However, this approach ignores the fact that there were many fewer individuals working at ages $65-67$, so the percentage point changes come from a much smaller base in that age range. The final column of Table 6 presents the ratio of the 2002 full-time workers to the 1998 full-time workers. For 62-64 year olds, the rate of full-time work increased by about 11 percent, while for 65-67 year olds it increased by about 22 percent. By this measure, abolishing the earnings test had a non-trivial effect, since the increase in full-time work was greater for those for whom the test was eliminated than for those for whom it remained in effect.

\section{IIIC. Simulations of the effects of abolishing the retirement earnings test between 62 and full retirement age.}

In this section we use the model, including the modification in which people are free to choose when to claim their benefits, to simulate the effects of abolishing the earnings test. This affects all respondents before age 65 and, for a substantial fraction of the sample, respondents who had already reached age 65 before the year 2000. Outcomes simulated include the effects of the earnings test on full and partial retirement and benefit claiming.

To briefly summarize our overall findings, from age 62 through the full retirement age, the remaining earnings test reduces the share of married men who work full-time by about four percentage points, which entails a reduction of about ten percent in the number of married men of that age at full-time work. In terms of the cash flow of the system, abolishing the earnings test would have an adverse effect, at least initially. If the earnings test were abolished between the early and full retirement ages, the share of married men claiming Social Security benefits would increase by about 10 percentage points, and the average benefit payments would increase by about $\$ 1,800$ per recipient. The initial increase in benefit payments would eventually be 
reversed, over a time span of decades, because the annual benefit amounts would eventually be reduced by more than an actuarially fair amount due to the earlier collection of benefits.

Our model also allows us to compare the effects of abolishing the earnings test with a policy that has a more favorable effect on the cash flow of the system. Instead of increasing the employment of older persons by abolishing the earnings test, their employment can be increased (by an even greater amount) by raising the early entitlement age under Social Security. A major difference on the funding side is that abolishing the earning test results in an earlier flow of benefit payments from Social Security, worsening the cash-flow problems of the system, while increasing the early entitlement age delays the flow of benefit payments from the system, improving its liquidity.

Implications for retirement outcomes.

Table 7 reports the differences in retirement outcomes between a simulation in which the earnings test is eliminated and the baseline results. There are two notable effects on retirement from abolishing the earnings test. As seen in the next to last column, from ages 62 to 65 , the percentage retired from full-time work is reduced by about four percentage points per year. With less than half the labor force still at full-time work, this entails an increase of about ten percent in full-time work by that population.

Some of those who remain at full-time work came from the ranks of the partially retired. As a result, there is a much smaller effect on the fraction of the labor force that is completely retired, ranging between a 1 and 2 percentage point decrease.

Notice the effect on the retirement spike at age 62 from abolishing the earnings test. The earnings test creates a link between the reward to work from continuing at full-time employment and the desire to claim Social Security benefits at age 62 for those with a high discount rate or 
low actuarial reward to postponed benefit receipt. This link encourages 3.8 percent of the population to retire at age 62 who would not otherwise retire if that link were not there. Therefore abolishing the earnings test would reduce the spike in retirements at age 62 by about 3.8 percentage points.

One other finding should be noted. In these simulations, abolishing the earnings test between early and full retirement age increases by 2 to 3 percentage points the fraction at fulltime work throughout the age range from 66 to 69 . There are two reasons for this finding. First, a number of those in the sample were born too soon to benefit from the abolition of the earnings test for those over the age of 65 in 2000. Second, others in the sample who were born in later years are facing an age 66 age of entitlement for full benefits.

Implications for the percent collecting Social Security benefits by age and the flow of Social Security benefits and taxes.

Table 8 projects the likely effect of abolishing the retirement earnings test on benefit claiming. The increase in claiming by the population ages 62 to 64 , seen in the last column of Table 8 , is ten to thirteen percent of the sample. By far the bulk of the increase in benefit payments are projected to come from the ranks of those holding full-time jobs, with 20 to 40 percent of persons remaining at full-time work claiming benefits at each year of age between 62 and 64 should the earnings test be abolished, with claiming increased through the age of 69 .

Table 9 details the changes in Social Security taxes paid and benefits received between simulations with and without the earnings test. Both taxes and benefits are weighted by the probability the individual survives to pay or collect them. The changes in Social Security taxes paid and benefits received are dependent both on changes in claiming behavior and on changes in employment induced by the removal of the earnings test. For those between the ages of 62 and 66, benefits are increased substantially after the abolition of the earnings test, ranging from 
$\$ 1,000$ to $\$ 2,300$ in additional benefits at each year of age. To attain actuarial balance, from age 70 onward, benefits are substantially reduced. Thus the abolition of the earnings test accelerates benefit payments by the Social Security Administration forward, and although reclaimed from a generation within the span of its lifetime, these payments are not reclaimed for the system for many years. That is, because the system is actuarially fair or more than actuarially fair, there is no loss to the system in present value terms from abolishing the earnings test, and perhaps even a small gain over the individual's lifetime. However, by the time the accelerated payments made to the first generation are recaptured, younger cohorts will be enjoying accelerated payments. Thus the system will take a hit to its liquidity on a one time basis that in a simple steady state would perhaps never be offset.

\section{D. Abolish the retirement earnings test between early and normal ages or raise the early entitlement age to 64 ?}

In an earlier paper we examined the effects of increasing the early entitlement age for Social Security benefits from 62 to 64 (Gustman and Steinmeier, 2005a). This is a policy that we expect to have similar effects on retirement as eliminating the earnings test between early and full retirement age. But we also expect raising the early entitlement age to have a more favorable effect on the liquidity of Social Security finances. ${ }^{15}$

Implications for retirement outcomes.

Column 3 of Table 10 indicates that increasing the early entitlement age to 64, leaving the earning test in place, would reduce the ranks of those retired from full-time work by over 7

\footnotetext{
${ }^{15}$ Gruber and Orzag (1999) suggest that eliminating the earnings test will have unfavorable effects on the distribution of benefits because those who claim their benefits early are left with lower benefits in later years, and those with lower lifetime earnings are more likely to claim their benefits early. Indeed, one consideration that mitigated against eliminating the earnings test between early and full retirement age by the Clinton Administration in 2000 was the specter of poor widows whose low benefits reflected the fact that their husband's elected to receive benefits early. Gruber and Orzag provide relevant descriptive numbers. They also note that the earnings test may favor high income individuals if their life expectancy is longer than those who are entitled to lower benefits. In the latter case, abolishing the earnings test may have a progressive impact on the distribution of benefits paid over the lifetime.
} 
percentage points at ages 62 and 63 . In contrast, Table 7 suggested that eliminating the earnings test would reduce the ranks of the retired by about 4 percentage points at each year of age from 62 to 66 , and by a smaller amount at older ages. Counting the labor market effects after age 66 , eliminating the earnings test appears to have a more powerful effect on the percentage at fulltime work, primarily due to the fact that the earnings test still affected many in the HRS sample who turned 65 before the year 2000. On the other hand, raising the early entitlement age appears to have a larger effect on the rolls of those who are completely retired.

These differences can be readily seen in Table 11. Entries in this table are the differences in retirement outcomes between a regime with an early entitlement age of 64 vs. a regime with no earnings test. For instance, at age 65 eliminating the earnings test would decrease the percentage retired from full-time work (increase full-time work) by 4.2 percentage points, as indicated in the third column of Table 7. At the same age, changing the early entitlement age would decrease the percentage retired from full-time work (increase full-time work) by 0.4 percentage points, as indicated in the third column of Table 10. The difference between these two scenarios is 3.8 percentage points, as indicated in the third column of Table 11. Overall, the percent retired from full-time work will be higher with an age 64 early entitlement age than under a regime where the earnings test is abolished. Compared to a regime with no earnings test, a regime with age 64 early entitlement would have 3.4 and 3.6 percentage points fewer people retired at ages 62 and 63, an additional 3.7 and 3.8 percentage points retired at 64 and 65, and would exhibit a 2.4 to 3.2 percentage point increase in the percentage retired from full-time work at each year of age from 66 to 69 . Implications for benefit claiming.

Table 12 shows the strong and obvious effect on benefit claiming of raising the early entitlement age to 64 . Table 13 shows the difference in benefit claiming between two regimes, 
the first where the early entitlement age is increased to age 64 , and the second where the earnings test is abolished. This table is the difference between the entries in Table 12 and the corresponding entries in Table 8 , with negative numbers indicating that benefit claiming is higher if the earnings test is eliminated than if the early entitlement age is increased. From the last column in Tables 12 and 13, we see that raising the early entitlement age to 64 would reduce the overall claiming by more than 40 percentage points at ages 62 and 63 , and by more than 50 percentage points as compared to a scenario where the earnings test is eliminated. In Table 13, the numbers continue to be negative after age 64 , largely because the elimination of the earnings test increases benefit claiming by those who remain at full-time work. Implications for the flow of taxes and benefits.

In Table 14, we see the effect of increasing the age of early entitlement on the flow of taxes and benefits. The impact on the flow of taxes is relatively minor. However, postponing the early entitlement age to 64 would result in a reduction in benefit payouts. It would take fifteen or twenty years before the missed benefits are compensated for by higher subsequent benefit payments, thus working in the direction of reducing, at least for a time, the cash flow problems of the system.

\section{Effects of changing minimum hours constraints.}

A minimum hours constraint is a limitation imposed by the firm requiring a minimum number of hours of work for a specified job. It has been known for some time that most jobs do not permit a person to retire gradually by reducing hours of work. ${ }^{16}$ The choice facing most workers on their long term jobs is to work full-time or not at all. Theory tells us that in the absence of any constraints (minimum hours constraints or a fixed cost of work), most people

\footnotetext{
${ }^{16}$ Gustman and Steinmeier $(1983,1984 a)$ document the existence of minimum hours constraints facing retirement age workers. Even and Macpherson (2004) use HRS data to discuss the relation between coverage by pension plans of different types and minimum hours constraints.
} 
would prefer to reduce their time at work gradually as they age. Moreover, given the higher wage paid on jobs held for a long time, they would prefer to partially retire on their long term jobs. As a result of the minimum hours constraints imposed by their employers, however, they are not free to do so. ${ }^{17}$ Consequently, the predominant retirement path is from full-time work to complete retirement, with a significant fraction, but still a minority, passing through partial retirement (Gustman and Steinmeier, 1984b, 2000). ${ }^{18}$ Should tighter labor markets encourage firms to relax their minimum hours constraints, the frequency of partial retirement will increase, while both full retirement and full-time work will become less common.

To simulate the effects of removing minimum hours constraints, all individuals are assumed to be able to switch to partial retirement in their full-time job with no change in wage rate, so they are paid half the earnings for half the work. This affects all respondents except those in full-time jobs which began prior to age 50 and which would allow half-time work in those jobs. Implicitly, this assumes that respondents could collect their full pensions at the age they change from full-time work to part-time work. Thus the simulation assumes the policy change deals with two of the major issues limiting part-time work: hours constraints are relaxed and in addition, the current law prohibiting paying a pension to a person who continues to work for the firm is eliminated. ${ }^{19}$

\footnotetext{
${ }^{17}$ Gustman and Steinemeier (1983) and Hurd (1996) list a number of reasons why firms choose to adopt minimum hours constraints, including fixed costs of employment, team production and other factors.

${ }^{18}$ Gustman and Steinmeier (1986) demonstrate the importance of including minimum hours constraints in structural retirement models. When these constraints are the reason most workers proceed directly from full-time work to complete retirement, but a model assumes workers are free to work part-time on their main job but choose not to, the resulting estimates will suggest that work and leisure are very close substitutes. Thus the model will generate corner solutions, with most individuals moving immediately from the corner with full-time work to the corner with full retirement. Once it is recognized that minimum hours constraints prohibit most older workers from phasing smoothly into retirement, preference estimates will show that in the absence of these constraints, most people would prefer to reduce their time at work smoothly as they phase into retirement, but their firms' policies prevent them from doing so.

${ }^{19}$ The simulations also eliminate the disincentive to partial retirement by those with DB plans who might find their benefits reduced when part-time wages earned at the end of the life cycle are counted when computing the average
} 
A comparison of panel 2 with panel 1 of Table 15 clearly indicates that if demand side changes persuaded firms to allow partial retirement at the same hourly wage as earned on the long term job, this would generate a major change in retirement outcomes. The percent of the labor force that passed through partial retirement would increase from about three tenths to about two thirds. To make the differences easier to follow, the first panel of Table 16 reports the difference in retirement outcomes between a simulation where there are no constraints on partial retirement and a simulation with the current restrictions on partial retirement. From the first row, when partial retirement is unconstrained, the fraction completely retired declines by 4.7 to 14.1 percentage points at each year of age between 58 and 65 . For ages 67 and 69 , the number who are completely retired falls by 15.3 and 13.8 percentage points respectively. From row three, the percent who are not retired at all also declines. The percentage not retired falls at each age, from a reduction of 7.5 percentage points at age 58 to a reduction of 8 percentage points at age 65 . The reductions in full-time work and in complete retirement flow into the ranks of the partially retired.

Comparing the change in the percent completely retired from full-time work with the change in the percent partially retired, the effect on total earnings is roughly a wash, or perhaps suggests a slight decline. The increase in partial retirement is roughly twice the reduction in fulltime work. Since the simulation suggests twice as many hours worked in a full-time job as when partially retired, this change suggests that work lost through acceleration of retiring from fulltime work is roughly balanced by the fact that twice as many people now work part-time. On

wage measure used in a final average salary benefit formula. When we abolish the hours constraint and let individuals draw on pensions when they partially retire, the pensions are calculated as though they quit at that point. Earnings and service during the period of partial retirement are not included in the pension calculation. For further discussions of the ERISA rule prohibiting a person from working part-time while collecting a pension benefit from a long term employer, see Fields and Hutchens (2002), Even and Macpherson (2004), and Penner, Perun and Steurle (2002). 
balance, roughly half the increase in partial retirement comes from full-time work, and half comes from full retirement, but the amount coming from full retirement increases with age, while the amount coming from the ranks of the not retired is greatest in the age range from 58 to 65 .

For those 65 to 69 , the opportunity to work part-time increases the number partially retired by about 20 percentage points. It reduces the number working full-time by $8,5.9$ and 3.1 percentage points at ages 65,67 and 69 respectively. Consequently, for those 65 and above, the increase in part-time workers is much greater than twice the decline in full-time workers, suggesting a 3 to 5 percentage point increase in full-time work equivalents from ages 65 to 69 . In this age range, partial retirement becomes three or four times more common than full-time work, as compared to being roughly equally common in the current environment.

\section{How do provisions of personal accounts affect retirement?}

To simulate behavioral responses to personal accounts, we use current law projections, meaning that the population is assumed to have been covered over their full lifetimes by the final set of Social Security rules now on the books. These rules include a normal retirement age of 67, a delayed retirement credit of 8 percent, and a payroll tax contribution of $10.6 \%$ of wages.

The policies are simulated by altering the budget constraint described above to build a baseline partial, voluntary personal account system, and then to simulate the effects of changing various features of the system. The incentives created by each alternative proposal generate behavioral responses. Given the resulting earnings histories and the choice to participate in a personal account, there is a string of tax contributions to the conventional system and to the personal accounts. The course of the conventional benefits depends both on the offset rule adopted for reducing conventional benefits when a person chooses to participate in a personal account, and on claiming behavior. 
Alternative policies will create different substitution and wealth effects. Under the current system, benefit recomputation means that a person who has been working 35 years enjoys a gain in benefits from another year of work that depends on the relation of earnings in the marginal year to the lowest indexed earnings used in computing Average Indexed Monthly Earnings among all previous years of work. After discounting, the marginal value of any additional future benefits less the value of foregone benefits will be added to the wage to determine the value of total compensation from continued work. If there are partial personal accounts, and if the interest rate earned on assets in the personal account is high enough, the substitution effect from a personal account may encourage a further delay in retirement. As long as benefits are higher with the personal account than without it, there also will be a wealth effect; but that will encourage earlier retirement.

A major caveat pertains to the absence of adjustments for risk. The additional benefits resulting from the higher return on personal accounts are not risk adjusted. We use a long run historical return for a mixed stock and bond portfolio that is meant to be reasonably conservative. Thus we assume that 45 percent of the portfolio is invested in treasury notes. However, we do not assume here that participants treat the equity premium, any additional returns to stocks over bonds, as due solely to risk. As a first approach to dealing with risk, we vary the discount rate. In particular, we use a lower interest rate than 4.31 percent real. Thus one way to interpret these results is as a sensitivity analysis to risk adjustment of the returns to the portfolio. Another is as a sensitivity analysis to the assumed level of returns in the absence of risk adjustment. It is important to note that because we ignore the risk of further declines in Social Security benefits, there is some balance in our assumptions. That is, although there is no risk adjustment in the returns to the personal accounts, there also is no risk adjustment to Social Security benefits under 
to reflect perceived political risk. Only one type of risk is explicitly taken into account.

Respondents do value the insurance provided by the annuity.

\section{VA. Structure of baseline personal accounts}

We begin by specifying a baseline personal account, and then explore the effects of changing some of its key characteristics. The baseline personal accounts are presumed to work the following way. At the time the individual registers for benefits, the Primary Insurance Amount (PIA) is reduced to take into account the contributions to the personal accounts. ${ }^{20}$ The resulting amount is the modified PIA. The personal account is divided into two parts. One part is required to be annuitized into a real annuity at the real interest rate and brings the total of the PIA plus the required annuity up to a minimal level. The other part is allowed either to be taken as a lump sum or annuitized, as the individual prefers. Further details of the process are contained in the following paragraphs.

The baseline accounts are financed with a 4 percentage point payroll tax rate taken from current payroll taxes. It is assumed that the accounts are voluntary. Accordingly, total utility is calculated both with and without the personal accounts, and the individual is presumed to choose whichever yields the most utility. This is an either / or decision; either the individual eschews personal accounts completely or invests in them to the permissible amount. We do not examine the case where the contribution decisions can differ year to year. Nor do we examine cases where the wife's participation decision is different from the husband; if the husband chooses personal accounts, the wife does as well.

\footnotetext{
${ }^{20} \mathrm{We}$ assume that benefits in the traditional account are reduced via a prorata method. The pro-rata method uses two hypothetical accounts. The first accumulates cumulatively the contributions to the private accounts at the offset rate of 2.5 percent real, which is the interest rate specified in the President's Commission's model 3. The second accumulates cumulatively the contributions to the traditional system, also at 2.5 percent real. Benefits are reduced by the percentage of the sum of the cumulative accounts that is due to the contributions to the private accounts. In the current law projection case, with partial accounts this is $4.0 / 10.6=37.7 \%$, which is the amount by which traditional benefits are reduced. This applies to the individual's own benefits and the spouse's spouse and survivor benefits which are due to the individual's earnings.
} 
In the baseline package, there is a minimum required annuity. The sum of the traditional benefit (PIA) plus required annuities from the personal accounts for the two spouses must reach the family poverty level. After that the beneficiary is free to take the payment as a lump sum, beginning at age $62 .^{21}$ At the time of the individual's application, the sum of the individual's PIA plus the spouse's then current PIA is subtracted from the family poverty level. The difference is what the two required annuities must cover. The required annuity for the individual is the total required annuity times the ratio of the individual's PIA to the sum of the two PIA's.

There are other assumptions underlying the specification of the basic package of personal accounts. The earnings test is assumed to apply proportionately to the two benefits. That is, the test is applied to the sum of the traditional benefits plus the required annuities to calculate the percent of benefits that are lost. ${ }^{22}$

Any sum accumulated in the personal accounts above the required level of annuitization is presumed to be available as a lump sum payment at age $62 .^{23}$

${ }^{21} \mathrm{We}$ also consider the effects of requiring the sum of the adjusted traditional PIA plus the required annuities to reach the single person poverty level; or the sum of the adjusted traditional PIA plus the required annuities to reach the unadjusted traditional PIA level (which is the amount that would be calculated from the current formula). The larger the required annuity, the less influential lump sum benefits are on retirement and retirement benefits.

${ }^{22}$ It is difficult to conceive of a system that would apply the earnings test to the lump sums, since the lump sums are almost by definition amounts that are above the amounts required to achieve the desired level of annual benefits. Similarly, the fate of any new contributions to the personal accounts depends on the status of the accounts. If the required annuities do not exhaust the accounts, then the contributions would be available, plus interest, in the next year. If, however, the accounts are insufficient to bring the total annuities up to the required levels, then any new contributions would go to purchase additional annuities to narrow the shortfall. For instance, suppose that traditional benefits are $\$ 8,000$ and the required annuities from the personal accounts are $\$ 4000$. If the earnings test limit is $\$ 6,000$ with a $\$ 1$ reduction for every $\$ 2$ in earnings above that amount, and if earnings are $\$ 20,000$, then $\$ 7,000[=0.5 *(20,000-6,000)]$ in benefits are lost. Two thirds of this $(\$ 4,667)$ are lost from the traditional benefits and one third $(\$ 2,333)$ is lost from the required annuities from the personal accounts, since the unreduced traditional benefits are two-thirds $[=8,000 /(8,000+4,000)]$ of total unreduced benefits. The lost traditional benefits increase later traditional benefits in the usual fashion. For the benefits that are lost from the required annuity, the lost benefits are invested at the real rate of return, and the following year the amount is annuitized and added to the previous required annuity.

${ }^{23}$ We also analyzed whether the required and optional annuities purchased from the personal accounts are to be single life or joint and two-thirds annuities. The presumption is that the eventual regulations would probably require joint annuities, but this investigates whether there is any substantial change in behavior as a result. When 


\section{VB. Participation in Personal Accounts}

Each simulation is done twice, one in which personal accounts are available and one in which they are not. The one with the highest lifetime total utility is presumed to be chosen. Since there is no uncertainty regarding the returns, almost all of the middle and high income households choose personal accounts, and most of the low income households do as well, especially those who retire at younger ages.

Participation in these personal accounts is very high. This is not a behavioral outcome, but is the result of construction of the model. We have assumed away uncertainty in the returns to the account. When we tabulate the proportion choosing personal accounts, since there is no stock market investment risk in this model, most people choose to participate. Only about 2 percent of all husbands from two-earner households choose not to participate, and among the bottom third of earners, 5 percent choose not to participate. When the individual is allowed to fully withdraw benefits in the form of a lump sum, participation in personal accounts rises to above 99 percent, with 98 percent of the low earners choosing to participate.

\section{VC. Personal accounts and retirement outcomes}

Table 17 presents retirement outcomes at age 62 under alternative specifications of systems of personal accounts. The first three columns report the cumulative levels of the fractions of married men who are not retired, partially retired and fully retired. The last column reports the percent retiring from full-time work at age 62 .

For purposes of comparison, line 1 of Table 17, and subsequent tables, report retirement outcomes assuming provisions of current law were fully implemented for the entire work lives of

single annuities are permitted, there is little change in retirement. But total benefits are higher under single annuities. A disproportionate amount of these benefits are taken at age 62, so that benefits received in one's late 70's or 80's are lower than in the basic package, despite the fact that total benefits are higher. 
the sample of married HRS respondents. By age 62, almost 44 percent of the population of married men is projected to be fully retired, with almost 42 percent reporting themselves as not retired. At age 62, column 4 indicates that 15.6 percent of married men are retiring from fulltime work.

Line 2 indicates retirement under the baseline reform package of personal accounts. As seen by comparing lines 1 and 2 of Table 17, the base package of personal accounts substantially increases retirements by age 62 , raising the percent fully retired from 43.8 percent to 57.6 percent, while reducing the fraction not retired by 9.1 percentage points, and reducing the fraction partially retired by 4.7 percentage points. ${ }^{24}$

There are a number of major forces operating to influence retirement under the baseline system of personal accounts. First, there are the conventional substitution and income effects. Given the higher return to investment, the system of personal accounts raises total benefits in retirement, creating an income effect encouraging earlier retirement. On the other hand, under a system of personal accounts, there is a greater reward to continued work for higher income people who otherwise would be in the 15 percent PIA bracket.

Row 3 of Table 17 reports retirement outcomes under a system where the conventional Social Security payroll tax may be entirely converted to a personal account. Comparing lines 2 and 3 thus allows comparison of a system with partial conversion to personal accounts, that is a

\footnotetext{
${ }^{24}$ There is a secondary spike at age 70 , but that is an artifact of the simulations, which assume that all individuals retired at that age.

Although the returns on personal accounts can average out over time, there is a problem when the accounts are annuitized. If the annuities are variable annuities, similar to the annuities TIAA-CREF offers, the value of the benefits will fluctuate year to year, sometimes by substantial amounts, and this runs counter to having a reliable income stream during retirement. If the annuities are fixed in real terms, then it may make a great deal of difference when the annuitization takes place. An individual who annuitized in 2000 , for instance, would have twice the annuity as another individual with similar lifetime earnings and contributions who annuitized in 2003. The unequal treatment of roughly equal individuals would make the differences involved in the "notch generation" debate small by comparison, and that debate generated a fair amount of heat. This annuitization problem may be substantial.
} 
system based on 4 percentage points of a payroll tax, with a system where the full 10.6 percent payroll tax may be converted to a personal account. While the fraction fully retired at age 62 is $57.6 \%$ under a system where the account may include up to 4 percentage points of the payroll tax, it is $63.2 \%$ where the full payroll tax may be included in the account. The fraction not retired would decline from $32.8 \%$ under a partial system of personal accounts, to $27.9 \%$ if the full payroll tax could be included in the personal account, and there would be a .7\% difference in the fraction partially retired.

\section{VD. The choice between lump sum payments and annuitized benefits}

Defined contribution pension plans often offer the option of a lump sum. Indeed, DC plans rarely offer the option of annuitizing benefits. In the case of personal accounts, the presumption is that even though the system is switching from a defined benefit to a defined contribution approach, the defined contribution plan will come with an annuity.

Retirement may be affected by whether benefits are offered only as an annuity as under the conventional Social Security program, or whether benefits may be taken as a lump sum. Those with high time preference rates, especially those in the population with a time preference rate well above the interest rate, who are more likely to accrue little saving, are more likely to value a lump sum benefit over an annuity that is of equal present value. For these people, allowing lump sum payouts may create a stronger incentive to retire early. When a lump sum is claimed by those with little other saving, it is likely to be consumed over the next few years, driving down the marginal utility of income from work. As a result, many of those with a high rate of time preference will leave work at age 62 .

Lines 4 and 5 of Table 17 clarify the effects on retirement of allowing lump sum benefits. The simulation in line 4 pertains to a system requiring that all benefits from personal accounts be 
fully annuitized. The higher return to personal accounts creates a wealth effect that exceeds the substitution effect, and thus encourages earlier retirement. The underlying interest rate is well below the time preference rates estimated above for an important fraction of the population, so these individuals will retire early just as they did when facing the conventional benefit structure. However, they do not receive a lump sum benefit, and thus place a higher value on work around age 62 than they would if a lump sum benefit were available. Requiring complete annuitization of benefits from the personal account would reduce the fraction fully retired at age 62 down to 48.3 percent.

Remember that the availability of lump sum benefits at age 62 is not conditioned on whether a person is working. The earnings test applies only to benefits from the conventional system plus benefits from the annuities paid out of the personal account. The present simulations do not provide a mechanism for clawing back any lump sum payments at age 62 should the individual continue working in a job offering long term employment.

Comparing rows 1, 2 and 4 helps us to decompose the decrease in retirement when transitioning from the current system to the baseline system of partial personal accounts. This comparison suggests that 9.3 percentage points of the increase in the fraction fully retired (column 3, row 2 minus row 4) results from the depressing effect of the lump sum payment at age 62 on the marginal utility of work, and 4.5 percentage points of the increase in retirements (row 4 minus row 1) is due to the income effect from receiving higher retirement benefits, net of substitution effect resulting from a higher reward to work at later ages. Analogously, the fraction retiring at age 62 is 18.9 percent when full annuitization is required, up from 15.6 percent under the current system, but would rise to 21.6 percent under the basic, voluntary partial personal account plan. There is a further effect from introducing personal accounts. Specifically, a 4.7 
percentage point reduction in the fraction partially retired appears to be almost entirely due to the effects of making lump sum payments available at age 62, with their depressing effects on the marginal utility of consumption for those with high discount rates, rather than to the wealth effect of the higher returns to personal accounts. When the package of personal accounts is introduced, partial retirement falls from 14.3 percent to 9.6 percent. Accordingly, introducing personal accounts reduces work effort by reducing both full-time work and partial retirement. ${ }^{25}$ However, 15 percent of the population chooses partial retirement when personal accounts are introduced, but lump sum benefits are not available, so the income effect from personal accounts explains almost none of the decline in partial retirement.

Column 4 of Table 17 shows that the fraction leaving full-time work increases from 15.6 percent under the current system to 21.6 percent under the basic voluntary system. Alternatively, as seen in Row 5 of Table 17, if complete lump sum withdrawals were permitted, that is, even those with below poverty incomes were not forced to annuitize a minimum benefit, full retirement would rise to 60.3 percent, with only 31.2 percent not retired at age 62 .

We also conducted a number of other simulations. One result is that the choice of offset method used to reduce traditional benefits has little effect on retirement outcomes. ${ }^{26}$ Further

\footnotetext{
${ }^{25}$ The increase in the lifetime value of personal account benefits when the personal account must be fully annuitized is a reflection of the effect of additional work on earnings, and thus on benefits.

${ }^{26}$ Using an alternative offset method similar to that used by the President's Commission did not have major effects on the findings. In simulations with offsets, it was assumed that the personal accounts were mandatory. With certain returns in the personal accounts that were higher than the offset interest rate, the model would show that everyone would prefer the personal accounts were they voluntary. Here the contributions to the personal accounts are cumulated at the offset rate of 2.5 percent real. The resulting amount is then discounted to the normal retirement age at 2.5 percent real and transformed into a single annuity at the same interest rate. This puts the offset computations on a comparable basis with the PIA, which is the traditional benefit available at normal retirement. Traditional benefits are then reduced by the ratio of this annuity to the PIA. The reduction applies to the individual's own benefit only, and not to any spouse or survivor benefits which depend on the individual's earnings record, since the offset account is annuitized with a single life annuity. A joint annuity would be very difficult to compute, since the spouse benefits depend on the relation of half of the individual's PIA to the spouse's PIA, and the applicable spouse's PIA may well not have been determined at the time the individual applies for benefits. For further discussion of alternative offset methods, see Gustman and Steinmeier (2005c). There we show that the offset method adopted by the President's Commission essentially taxes away the principal created in the private account
} 
simulations show the larger the required annuitization, and thus the smaller the lump sum benefits that can be claimed, the lower the retirement rate as a result of adopting personal accounts.

To provide symmetric results for saving behavior, Table 18 shows the total value of nonpension, non-Social Security wealth that is accumulated under alternative plans. Components of wealth measured by the HRS include retirement assets such as IRAs, real estate, business and financial assets, and other forms of wealth (see Gustman and Steinmeier, 1999 for a detailed analysis). Comparing rows 1 to 3 at various ages, total wealth is lower where personal accounts are more valuable, suggesting there is some substitution between personal accounts and these other forms of wealth.

As seen in Table 19, simulations for the basic package of personal accounts suggests that 46.2 percent will choose a lump sum payment, 48.5 percent will choose a voluntary annuity, and 5.4 percent will not have sufficient annuitized benefits to allow them to take a lump sum. That is, they will not have an annuity equal to the family poverty level. The earlier one retires the greater the proportion choosing to accept a lump sum payment from their personal accounts rather than annuitizing funds available for a voluntary annuity. For example, as seen in Table 19 , for the base package of personal accounts, almost two thirds of those retiring in their early fifties choose to take a lump sum settlement when they reach age 62 , while 40 to 47 percent of those retiring between 58 and 62 choose a lump sum settlement. Seventy percent of those retiring at exactly 62 choose a lump sum settlement. Among those retiring from age 63 on, only about a fifth will choose a lump sum settlement over annuitized benefits.

from payroll tax deposits made in the name of the covered individual. That reduces the insurance the account would otherwise provide against unforeseen changes in Social Security benefits that might be adopted in the future. 
Table 2 in the Appendix shows how the proportion choosing lump sum vs. voluntary annuities out of the discretionary funds in the personal accounts varies among the different plans. Discretionary funds are those in excess of any annuity that is required to ensure that retirement income meets the minimum level specified in the plan. For most variations of the personal account plans, about half of participants choose to take their benefits from the personal account as a lump sum. We will see below that the decision to accept a lump sum benefit will affect the distribution of retirement income at different ages.

\section{VE. Benefits by Age}

Despite having only modest effects on retirement, the features of these alternative systems have major effects on retirement incomes of the covered populations. Where annuitization is not mandatory, as noted in Table 19, many will choose to take lump sum payments at age 62. Thus we see in Table 20A in those programs where lump sum payments are permitted, i.e., in rows 2, 3 and 5, the average benefit taken at age 62 (in 1992 dollars) is equal in dollar amount to two to four times the average yearly annuitized benefit paid at age 70 .

In contrast, as seen in row 4 of Table $20 \mathrm{~A}$, in plans for personal accounts where full annuitization is required, the average benefit taken at age 62 is much lower than the average benefit at age 70, as many put off benefit claiming until a later age. Moreover, within those plans allowing a lump sum payment, the lower the required annuity, and the higher the permitted lump sum, the smaller the yearly benefit at older ages compared to the benefit at age 62 .

One issue is how widows will fare if lump sum benefits are claimed at age 62, either by the family when both spouses are alive, or by the widow. Table 20B shows that spouses on average will be just as well off under the baseline system of partial privatization as under the current program, assuming the $4.31 \%$ real return to the personal account portfolio. Scanning 
down the benefits by program for 85 year olds, widow's benefits will be higher than under the current program only if there is complete conversion of the current system to personal accounts, or if under a plan with partial personal accounts, annuitization is mandatory.

The average benefits by program and by age do not tell the full story. There will be a distribution of benefits at each age that depends on the distribution of choices made as to whether to participate in the personal account (most will), and as to whether to take a lump sum benefit, or to fully annuitize the assets in the personal account.

\section{VF. Taxes and Benefits Under Personal Accounts}

Total taxes and benefits over the lifetime are shown in Table 21, where taxes and benefits are shown in 1992 dollars, adjusted for mortality, but not discounted. Total taxes paid decline by 1.2 percent under the baseline personal account program, compared to the current law projections for traditional Social Security benefits. In addition to the decline in total taxes paid, there is a much larger decline in taxes paid into the trust fund as taxes are diverted to personal accounts. For the baseline personal account program, the maximum decline in taxes paid into the trust fund due to diversion of taxes from conventional benefits to personal accounts is 37.7 percent $(4 / 10.6){ }^{27}$

Table 21 also shows the decline in lifetime benefits from $\$ 328,955$ to $\$ 199,878$, or almost 40 percent. Thus the decline in benefits and taxes from adoption of personal accounts are roughly of the same proportion. However, because taxes are reduced years before benefits are reduced, the movement to personal accounts does present a solvency problem. Given the assumption of a real return to the personal account portfolio of 4.31 percent per year, and the heavy pattern of participation in these accounts, the increase in total benefits, i.e. the sum of benefits from the traditional system and from personal accounts, is substantial, rising from $\$ 328,955$ to $\$ 410,4344^{28}$

\section{Conclusions}

\footnotetext{
${ }^{27}$ The actual decline in taxes is slightly less than 37.7 percent since 5 percent of covered workers will choose not to accept the personal account, and these will mainly come from the ranks of low income workers.

${ }^{28}$ This calculation does not take into account any risk premium either for stock market investment, or the political risk to current Social Security promises.
} 
This paper has examined retirement and related responses to a number of policies. We call these the next generation of policies because the changes they introduce are, on average, roughly actuarially neutral. They are in contrast to decades of policy changes that removed disincentives to continued work from unfair actuarial adjustments. Nevertheless, retirement is affected by these actuarially neutral policies as those with high time preference rates do not find the promise of additional future rewards to balance the loss in current benefits.

We can summarize our findings with regard to four different types of policy initiatives, none of which involves a primary manipulation of the actuarial reward to deferred benefit receipt.

\section{A. Abolishing the retirement earnings test.}

For persons between the early entitlement and full retirement age, the earnings test is actuarially fair, or better than fair. Future benefits are increased so that at the interest rate used in the calculation, they at least compensate for any benefit reductions from the earnings test for earnings that exceed the annual exempt amount. Consequently, a prediction of life cycle models with perfectly operating capital markets is that the earnings test should not affect retirement behavior. Nevertheless, we have found that a number of people have high rates of time preference, and they do not consider the restoration of benefits on an actuarially fair basis, using the government's interest rate, to be an attractive tradeoff.

From age 62 through the full retirement age, the earnings test reduces the share of married men who work full-time by about four percentage points, which entails a reduction of about ten percent in the number of married men of that age at full-time work. In terms of the cash flow of the system, abolishing the earnings test would have an adverse effect, at least initially. If the earnings test were abolished between the early and full retirement ages, the share 
of married men claiming Social Security benefits would increase by about 10 percentage points, and the average benefit payments would increase by about $\$ 1,800$ per recipient. The initial increase in benefit payments would eventually be reversed, over a time span of decades, because the annual benefit amounts would eventually be reduced by more than an actuarially fair amount due to the earlier collection of benefits.

As an alternative to increasing work effort by abolishing the earnings test, one can increase the employment of older persons by increasing the early entitlement age under Social Security. A major difference on the funding side is that abolishing the earning test results in an earlier flow of benefit payments from Social Security, worsening the cash flow problems of the system, while increasing the early entitlement age delays the flow of benefit payments from the system, improving its cash flow.

\section{B. Minimum hours constraints}

Minimum hours constraints, that is the requirements on many jobs that an individual work full-time or not at all, are a major firm-side factor affecting the course of retirements. Should minimum hours constraints be abolished, among the population ages 62 to 69 that has a long term commitment to the labor market, the percentage completely retired will decline by 10 to 15 percentage points, depending on age. The fraction in this age group working in partial retirement jobs will increase by roughly twenty percentage points. Were minimum hours constraints abolished, more than twice as many people would enter partial retirement as would leave full-time work, so that total full-time equivalent (FTE) employment would increase. But the change in FTE employment is much smaller than the increase in partial retirement employment. 
When firms decide whether to relax minimum hours constraints, they will consider not just the very modest effect on FTE employment from relaxing these constraints. They will also consider how minimum hours constraints contribute to productivity and reduce costs. Fixed costs of employment to the firm, the role of interdependence in production and many other factors have encouraged firms to adopt minimum hours constraints in the first place. Moreover, although our simulations have assumed that constraints on partial retirement from current pension rules are eliminated, health insurance and other benefits made available on a per employee, rather than per hour basis, increase costs when firms provide a partial retirement option.

Our findings also suggest that if firms relaxed minimum hours constraints, this would have conflicting effects on the flow of funds from Social Security. Relaxing minimum hours constraints would encourage individuals to leave full-time work at younger ages to enter partial retirement. As a result, they would begin to draw down their benefits at an earlier age, increasing the flow of funds out of Social Security. However, they would remain in partial retirement jobs past the point where they currently retire, and during this period they would draw fewer benefits. The proportion of earnings subject to the earnings test will also be subject to conflicting forces. The fraction of earnings exempt from the earnings test will increase, but the fraction of earnings beyond the reaches of the earnings test will decline. Lastly, behavior would change under proposed reforms that would include personal accounts as part of Social Security. Should firms relax minimum hours constraints to encourage more partial retirement by older individuals, demand for early withdrawals from personal accounts would increase. This would increase the importance of terms and conditions regulating the timing of withdrawals from personal accounts. 


\section{C. Introducing partial personal accounts.}

Particular features of personal accounts will affect retirement behavior, saving, and participation in personal accounts. These choices in turn will affect the flow of benefits and taxes, and ultimately the adequacy of benefits.

Among our findings, under a system of partial personal accounts, with higher average returns on portfolios than under the current formula (unadjusted for risk), total retirement benefits would increase by about a quarter, while the fraction of 62 year olds at full-time work would decline by about 22 percent compared to the current system. If the current system were replaced completely by personal accounts, total retirement benefits would increase by about 75 percent and the fraction at full-time work would decline by about a third.

Retirement responses are relatively modest, but the predicted increase in retirements from adopting partial personal accounts should nevertheless be of concern to policy makers. Increased retirements will further reduce the labor supply of older workers beyond the decline caused by the retirement of the baby boom.

\section{D. Annuities vs. lump sums.}

If all benefits from personal accounts could be taken as a lump sum, the fraction not retired at age 62 would fall by about 5 percentage points compared to a system where there is mandatory annuitization of benefits. When annuitization is voluntary, there will be substantial diversion of benefits to age 62 . When annuitization is mandatory, benefits received in one's 70 s and 80 s may be increased by 20 percent or more. These findings suggest that the ongoing transition from annuitized benefits to systems with increased availability of lump sum payouts will encourage increased retirement. This side effect of transitions to plans offering lump sum 
payouts will act to undermine the thrust of the first generation of policies designed to encourage later retirements.

\section{E. In summary}

As we have emphasized throughout this paper, a key to understanding the effects on retirement of this next generation of policies is to understand saving and the role of heterogeneity in time preference. A significant fraction of people in the labor market has a high time preference rate. These people will not find tradeoffs between foregone present benefits and increased future benefits at actuarially fair rates to be an attractive bargain. Some policies that are expected to have a large effect on retirements by introducing actuarially fair benefit adjustments will have smaller effects than expected. Other policies that are expected to have no effect on retirement because they involve transitioning from one actuarially fair benefit structure to another, such as abolishing the retirement earnings test between early and full retirement ages, nevertheless will affect retirements. In the case of abolishing the retirement earnings test, that policy will increase labor force activity and accordingly will encourage postponed retirements.

On the other hand, some policy changes, which again appear to be actuarially neutral, such as the trend to paying out retirement plan benefits as a lump sum instead of an actuarially equivalent annuity, will have the effect of encouraging earlier rather than later retirements. Models that jointly explain retirement and saving, and allow for heterogeneity of time preference rates, are required to understand the direction and size of the effects of these and related policies on retirement. 
Table 1

Estimated Results

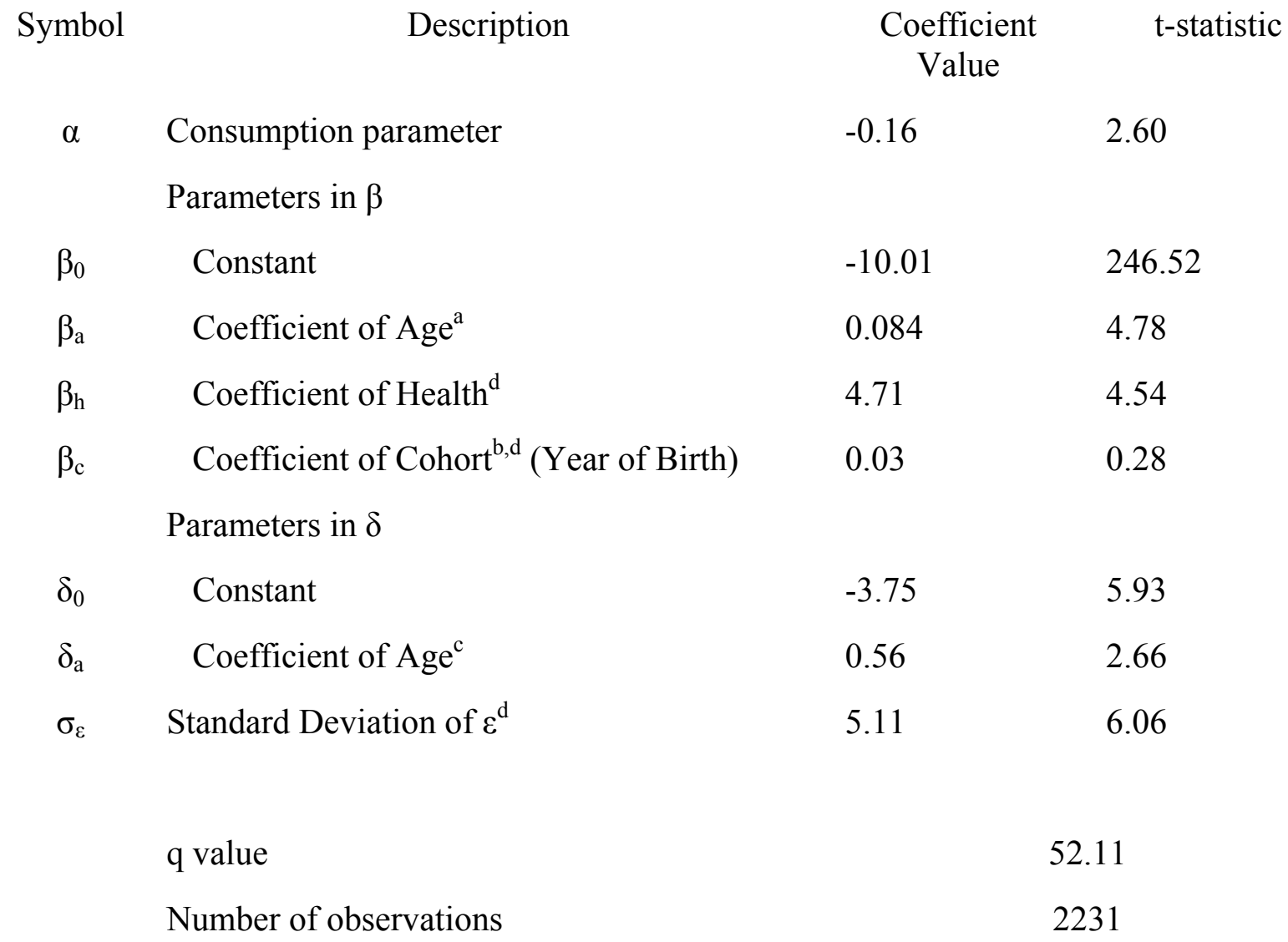

Several variables are differenced from their approximate means in the sample in order to facilitate estimation. They are:

a The actual variable is age - 62 .

b The actual variable is cohort - 1936 .

c The actual variable is age -65 .

$\mathrm{d}$ These coefficients are all relative to the age coefficient, again to facilitate estimation. 
Table 2: Observed and Projected Retirement Percentages

Observed Retirement Percentages

$\begin{array}{rr}\text { Percentage Retiring } \\ \text { From FT } \\ \text { Work } & \text { rompletely } \\ 4.1 & 3.3 \\ 0.9 & 0.0 \\ 2.7 & 2.2 \\ 2.0 & 1.1 \\ 2.1 & 1.3 \\ 3.1 & 2.7 \\ 1.9 & 2.1 \\ 4.0 & 3.2 \\ 3.0 & 2.1 \\ 3.6 & 2.1 \\ 6.0 & 6.4 \\ 6.3 & 5.5 \\ 15.1 & 12.5 \\ 5.6 & 3.4 \\ 6.7 & 6.7 \\ 9.1 & 6.7 \\ 4.5 & 3.9 \\ 2.8 & 2.9 \\ 3.1 & 3.3 \\ 1.7 & 4.6\end{array}$

$\begin{array}{rrr}\text { Percentage Retired } & \\ \text { From FT } & & \\ \text { Work } & \text { Completely } & \text { Observations } \\ 4.1 & 3.3 & 243 \\ 5.0 & 3.3 & 361 \\ 7.6 & 5.5 & 510 \\ 9.7 & 6.6 & 621 \\ 11.8 & 7.9 & 712 \\ 14.9 & 10.6 & 801 \\ 16.8 & 12.7 & 907 \\ 20.8 & 15.9 & 990 \\ 23.8 & 18.0 & 1064 \\ 27.4 & 20.1 & 1132 \\ 33.4 & 26.4 & 1121 \\ 39.7 & 31.9 & 1043 \\ 54.8 & 44.4 & 986 \\ 60.4 & 47.9 & 909 \\ 67.1 & 54.6 & 843 \\ 76.2 & 61.3 & 744 \\ 80.7 & 65.2 & 658 \\ 83.5 & 68.1 & 565 \\ 86.7 & 71.4 & 472 \\ 88.4 & 76.0 & 379\end{array}$

Projected Retirement Percentages

\begin{tabular}{rrrr} 
Percentage Retiring & \multicolumn{3}{c}{ Percentage Retired } \\
From FT & \multicolumn{3}{c}{ From FT } \\
Work & Completely & Work & Completely \\
4.5 & 3.1 & 4.5 & 3.1 \\
1.4 & 0.9 & 5.9 & 4.1 \\
1.7 & 1.2 & 7.6 & 5.3 \\
1.5 & 1.1 & 9.1 & 6.4 \\
1.9 & 1.4 & 11.0 & 7.8 \\
3.2 & 2.4 & 14.2 & 10.2 \\
3.2 & 2.4 & 17.4 & 12.6 \\
3.5 & 2.8 & 20.9 & 15.4 \\
4.2 & 3.4 & 25.1 & 18.8 \\
4.5 & 3.6 & 29.6 & 22.4 \\
6.5 & 5.3 & 36.1 & 27.6 \\
5.4 & 4.3 & 41.4 & 32.0 \\
14.8 & 10.3 & 56.2 & 42.2 \\
6.2 & 4.9 & 62.4 & 47.1 \\
5.9 & 4.9 & 68.2 & 52.0 \\
6.0 & 5.3 & 74.2 & 57.3 \\
4.5 & 4.1 & 78.7 & 61.3 \\
4.2 & 4.0 & 82.9 & 65.3 \\
3.7 & 3.3 & 86.6 & 68.6 \\
3.0 & 2.6 & 89.7 & 71.3
\end{tabular}

Total number of observed respondents: 2231 
Table 3: Social Security Benefit Receipt by Age and Retirement Status, 1994 to 2002

\begin{tabular}{|c|c|c|c|c|c|}
\hline Age & $\begin{array}{l}\text { Retirees from Full- } \\
\text { time Work }\end{array}$ & Fully Retired & Partially Retired & Full-Time Working & All \\
\hline 62 & 72.0 & 75.1 & 60.8 & 9.8 & 47.5 \\
\hline 63 & 83.7 & 86.5 & 73.1 & 17.3 & 61.7 \\
\hline 64 & 86.1 & 87.3 & 80.9 & 24.6 & 68.4 \\
\hline 65 & 92.2 & 91.9 & 93.5 & 59.9 & 84.6 \\
\hline 66 & 92.9 & 93.0 & 92.6 & 74.8 & 89.4 \\
\hline 67 & 95.4 & 94.7 & 98.1 & 76.6 & 92.0 \\
\hline 68 & 92.7 & 93.6 & 89.1 & 79.1 & 91.1 \\
\hline 69 & 94.4 & 95.2 & 90.8 & 81.7 & 93.1 \\
\hline
\end{tabular}

Observations for 1992 were excluded because unlike the questions in later years, the 1992 question on Social Security benefit receipt referred to receipt in the previous year. 
Table 4: Baseline Projections of the Percent of Married Men Collecting Social Security Benefits (Assuming the Earnings Test Is in Place and People Optimally Apply for Benefits)

Age

62

63

64

65

66

67

68

69

\section{Percent Collecting Social Security}

Retirees From

Completely

Retired

Partially Retired

Full-Time Work

All

53.5

60.0

74.8

92.0

94.4

97.1

98.4

99.1

76.4
79.0
84.0
93.3
96.1
97.7
98.7
99.2

76.4

79.0

84.0

93.3

96.1

98.7

99.2
19.4

22.7

27.8

65.8

79.2

87.0

92.3

94.7
41.3

48.1

60.1

84.7

91.0

95.2

97.4

98.5 
Table 5

Distribution of Observations Around Earnings Test Limit (Percentage of observations reported in cells)

\begin{abstract}
$50-\quad 60-\quad 70-\quad 80-\quad 90-\quad 100-\quad 110-\quad 120-\quad 130-\quad 140-$
$\begin{array}{llllllllllll}<50 \% & 60 \% & 70 \% & 80 \% & 90 \% & 100 \% & 110 \% & 120 \% & 130 \% & 140 \% & 150 \% & >150 \%\end{array} \quad$ All
\end{abstract}

Age Range

All observations with wage earnings

$\begin{array}{cccccccccccccc}62-69 & 14.0 \% & 3.7 & 3.3 & 3.3 & 3.7 & 4.2 & 3.0 & 2.5 & 2.5 & 1.5 & 2.2 & 56.0 & 100 \% \\ 62-64 & 10.5 & 3.1 & 2.6 & 3.1 & 3.0 & 4.0 & 2.8 & 2.5 & 2.5 & 1.7 & 2.4 & 61.8 & 100 \\ 65-69 & 27.7 & 5.9 & 6.2 & 4.0 & 6.3 & 5.0 & 3.7 & 2.3 & 2.9 & 0.9 & 1.3 & 33.6 & 100\end{array}$

Partially retired workers

$\begin{array}{cccccccccccccc}62-69 & 32.5 & 8.8 & 7.8 & 7.1 & 7.2 & 7.2 & 4.2 & 2.9 & 2.5 & 1.7 & 1.3 & 16.6 & 100 \\ 62-64 & 26.9 & 8.3 & 6.7 & 8.3 & 6.7 & 8.3 & 5.2 & 3.2 & 3.1 & 2.1 & 1.7 & 19.4 & 100 \\ 65-69 & 46.4 & 10.1 & 10.3 & 4.4 & 8.3 & 4.6 & 1.8 & 2.2 & 1.1 & 0.7 & 0.4 & 9.8 & 100\end{array}$

Full-time workers

$\begin{array}{llllllllllllll}62-69 & 1.9 & 0.6 & 0.7 & 1.1 & 1.7 & 2.5 & 2.3 & 2.2 & 2.6 & 1.5 & 2.7 & 80.2 & 100 \\ 62-64 & 1.4 & 0.4 & 0.5 & 0.6 & 1.2 & 1.9 & 1.6 & 2.2 & 2.2 & 1.5 & 2.8 & 83.6 & 100 \\ 65-69 & 4.6 & 1.4 & 1.9 & 3.8 & 4.6 & 5.8 & 6.0 & 2.4 & 4.8 & 1.2 & 2.4 & 61.2 & 100\end{array}$


Table 6

Percentages Working Full-Time by Age and Year

Age
62
63
64
65
66
67
68
69

$\begin{array}{cccc}1996 & 1998 & 2000 & 2002 \\ & & & \\ 28.7 \% & 29.4 \% & 32.4 \% & 32.7 \% \\ 25.3 & 25.8 & 28.1 & 27.5 \\ 21.2 & 21.9 & 23.2 & 25.3 \\ 14.2 & 16.2 & 18.8 & 20.7 \\ 13.7 & 14.0 & 13.7 & 16.4 \\ 15.2 & 11.4 & 11.5 & 13.9 \\ 10.6 & 10.3 & 10.8 & 12.2 \\ 9.4 & 9.3 & 8.8 & 10.3\end{array}$

2002-1998 2002/1998 Ratio Difference

$\begin{array}{cc}3.3 \% & 1.11 \\ 1.7 & 1.07 \\ 3.4 & 1.16 \\ 4.5 & 1.28 \\ 2.4 & 1.17 \\ 2.5 & 1.22 \\ 1.9 & 1.18 \\ 1.0 & 1.11\end{array}$


Table 7

Differences in Retirement Outcomes Between Simulations After Eliminating the Earnings Test and Simulations with the Earnings Test

\begin{tabular}{|c|c|c|c|c|}
\hline \multirow[b]{2}{*}{ Age } & \multicolumn{2}{|c|}{ Percentage Retiring } & \multicolumn{2}{|c|}{ Percentage Retired } \\
\hline & $\begin{array}{c}\text { From Full-time } \\
\text { Work }\end{array}$ & Completely & $\begin{array}{c}\text { From Full-time } \\
\text { Work }\end{array}$ & Completely \\
\hline 60 & 0.0 & 0.0 & 0.0 & -0.1 \\
\hline 61 & 0.0 & 0.0 & -0.1 & -0.1 \\
\hline 62 & -3.8 & -1.3 & -3.9 & -1.3 \\
\hline 63 & -0.3 & 0 & -4.2 & -1.3 \\
\hline 64 & -0.1 & -0.2 & -4.3 & -1.6 \\
\hline 65 & 0.1 & -0.1 & -4.2 & -1.7 \\
\hline 66 & 0.8 & 0.3 & -3.5 & -1.4 \\
\hline 67 & 0.5 & 0.0 & -2.9 & -1.3 \\
\hline 68 & 0.5 & 0.1 & -2.5 & -1.2 \\
\hline 69 & 0.4 & 0.1 & -2.2 & -1.1 \\
\hline
\end{tabular}


Table 8: Differences in Percent Collecting Social Security Benefits Between Simulations After Eliminating the Earnings Test and Simulations with the Earnings Test

\begin{tabular}{|c|c|c|c|c|c|}
\hline \multicolumn{6}{|c|}{ Differences in Percent Collecting Social Security } \\
\hline Age & $\begin{array}{l}\text { Retirees From } \\
\text { Full-Time Work }\end{array}$ & $\begin{array}{l}\text { Completely } \\
\text { Retired }\end{array}$ & Partially Retired & Full-Time Work & All \\
\hline 62 & -2.1 & -1.5 & -1.3 & 26.2 & 10.5 \\
\hline 63 & -1.6 & -1.0 & -0.8 & 30.8 & 11.0 \\
\hline 64 & -0.5 & -0.8 & 1.6 & 40.2 & 13.2 \\
\hline 65 & 0.3 & -0.1 & 1.9 & 22.4 & 6.4 \\
\hline 66 & 0.0 & -0.1 & 0.9 & 12.9 & 3.1 \\
\hline 67 & 0.2 & 0.0 & 0.8 & 9.1 & 1.9 \\
\hline 68 & 0.1 & 0.1 & 0.6 & 6.4 & 1.2 \\
\hline 69 & 0.0 & 0.1 & 0.3 & 4.8 & 0.8 \\
\hline
\end{tabular}


Table 9

Differences in Social Security Taxes and Benefits Between Simulations After Eliminating the Earnings Test and Simulations with the Earnings Test

$\begin{array}{ccc}\text { Age } & \text { Taxes } & \text { Benefits } \\ & & \\ 50 & 0 & 4 \\ 55 & 3 & 34 \\ 60 & 2 & 98 \\ 61 & 3 & 161 \\ 62 & 84 & 1487 \\ 63 & 90 & 1813 \\ 64 & 101 & 2322 \\ 65 & 111 & 1722 \\ 66 & 90 & 1020 \\ 67 & 79 & 674 \\ 68 & 67 & 310 \\ 69 & 57 & -80 \\ 70 & & -503 \\ 75 & & -809 \\ 80 & & -750 \\ 85 & & -574 \\ 90 & & -380 \\ 95 & & -210\end{array}$


Table 10

Effect on Retirement of Increasing the Early Entitlement Age to 64

Percentage Retiring

Age

58

59

60

61

62

63

64

65

66

67

68

69
From Full-time

Work

Completely

$-0.1$

$-0.1$

$-0.2$

$-0.4$

$-6.5$

$-0.5$

7.3

0.2

0.2

0.2

0.2

0.1
$-0.1$

$-0.1$

$-0.2$

$-0.4$

$-4.1$

$-0.4$

5.1

0.1

0.2

0.2

0.2

0.2
Percentage Retired

From Full-time

Work

$-0.2$

$-0.3$

$-0.4$

$-0.8$

$-7.3$

$-7.8$

$-0.6$

$-0.4$

$-0.3$

0.0

0.1

0.2
Completely

$-0.3$

$-0.3$

$-0.5$

$-0.8$

$-4.8$

$-5.2$

$-0.2$

$-0.1$

0.1

0.3

0.5

0.7 
Table 11

Difference in Retirement Outcomes Between Regime with Age 64 Early Entitlement and Regime with No Earnings Test

\begin{tabular}{|c|c|c|c|c|}
\hline \multirow[b]{2}{*}{ Age } & \multicolumn{2}{|c|}{ Percentage Retiring } & \multicolumn{2}{|c|}{ Percentage Retired } \\
\hline & $\begin{array}{c}\text { From Full-time } \\
\text { Work }\end{array}$ & Completely & $\begin{array}{c}\text { From Full-time } \\
\text { Work }\end{array}$ & Completely \\
\hline 58 & -0.1 & -0.1 & -0.2 & -0.2 \\
\hline 59 & -0.1 & -0.1 & -0.2 & -0.2 \\
\hline 60 & -0.2 & -0.2 & -0.4 & -0.4 \\
\hline 61 & -0.4 & -0.4 & -0.7 & -0.7 \\
\hline 62 & -2.7 & -2.8 & -3.4 & -3.5 \\
\hline 63 & -0.2 & -0.4 & -3.6 & -3.9 \\
\hline 64 & 7.4 & 5.3 & 3.7 & 1.4 \\
\hline 65 & 0.1 & 0.2 & 3.8 & 1.6 \\
\hline 66 & -0.6 & -0.1 & 3.2 & 1.5 \\
\hline 67 & -0.3 & 0.2 & 2.9 & 1.6 \\
\hline 68 & -0.3 & 0.1 & 2.6 & 1.7 \\
\hline 69 & -0.3 & 0.1 & 2.4 & 1.8 \\
\hline
\end{tabular}


Table 12

Effect on Benefit Claiming of Increasing the Early Entitlement Age to 64

Age
62
63
64
65
66
67
68
69

Retirees From
Full-Time Work
$\begin{gathered} \\ -59.9 \\ -65.1 \\ -0.6 \\ -0.2 \\ -0.1 \\ -0.1 \\ 0.0 \\ 0.0\end{gathered}$

Differences in Percent Collecting Social Security

$\begin{array}{cccc}\begin{array}{c}\text { Completely } \\ \text { Retired }\end{array} & \text { Partially Retired } & \text { Full-Time Work } & \text { All } \\ -53.5 & -76.4 & -19.4 & -41.3 \\ -60.0 & -79.0 & -22.7 & -48.1 \\ -0.6 & -0.6 & 0.7 & -0.5 \\ -0.2 & -0.3 & 0.5 & -0.1 \\ -0.1 & -0.3 & 0.1 & -0.1 \\ -0.1 & -0.1 & 0.0 & -0.1 \\ 0.0 & 0.0 & -0.2 & 0.0 \\ 0.0 & 0.0 & -0.2 & 0.0\end{array}$


Table 13

Difference in Benefit Claiming Between a Regime with Age 64 Early Entitlement and a Regime with No Earnings Test

\begin{tabular}{|c|c|c|c|c|c|}
\hline \multicolumn{6}{|c|}{ Differences in Percent Collecting Social Security } \\
\hline Age & $\begin{array}{l}\text { Retirees From } \\
\text { Full-Time Work }\end{array}$ & $\begin{array}{c}\text { Completely } \\
\text { Retired }\end{array}$ & Partially Retired & Full-Time Work & All \\
\hline 62 & -57.8 & -52.0 & -75.1 & -45.6 & -51.8 \\
\hline 63 & -63.5 & -59.0 & -78.2 & -53.5 & -59.1 \\
\hline 64 & -0.1 & 0.2 & -2.2 & -39.5 & -13.7 \\
\hline 65 & -0.5 & -0.1 & -2.2 & -21.9 & -6.5 \\
\hline 66 & -0.1 & 0.0 & -1.2 & -12.8 & -3.2 \\
\hline 67 & -0.3 & -0.1 & -0.9 & -9.1 & -2.0 \\
\hline 68 & -0.1 & -0.1 & -0.6 & -6.6 & -1.2 \\
\hline 69 & 0.0 & -0.1 & -0.3 & -5.0 & -0.8 \\
\hline
\end{tabular}


Table 14

Effect on Social Security Taxes and Benefits Claiming of Increasing the Early Entitlement Age to 64

$\begin{array}{ccc}\text { Age } & \text { Taxes } & \text { Benefits } \\ & & \\ 50 & 0 & -5 \\ 55 & 1 & -42 \\ 60 & 13 & -175 \\ 61 & 23 & -313 \\ 62 & 166 & -2738 \\ 63 & 176 & -3532 \\ 64 & 10 & -529 \\ 65 & 6 & -502 \\ 66 & 2 & -436 \\ 67 & -3 & -82 \\ 68 & -8 & 249 \\ 69 & -10 & 433 \\ 70 & & 545 \\ 75 & & 825 \\ 80 & & 774 \\ 85 & & 609 \\ 90 & & 420 \\ 95 & & 239\end{array}$


Table 15

Results of Retirement Simulations from Relaxing the Indicated Factor (Numbers reported are in percentages)

\begin{tabular}{|c|c|c|c|c|c|c|c|c|}
\hline Age & 55 & 58 & 60 & 62 & 65 & 67 & 69 & $\begin{array}{l}\text { Percent into } \\
\text { partial } \\
\text { retirement }\end{array}$ \\
\hline $\begin{array}{l}\text { Full Sample Baseline } \\
\text { percent completely retired }\end{array}$ & 8.8 & 17.5 & 26.5 & 40.2 & 56.5 & 66.1 & 76.7 & \\
\hline percent partially retired & 4.1 & 6.4 & 8.7 & 13.5 & 15.7 & 15.5 & 13.0 & 29.9 \\
\hline percent not retired & 87.1 & 76.1 & 64.8 & 46.3 & 27.8 & 18.4 & 10.3 & \\
\hline $\begin{array}{l}\text { No Hours Limits } \\
\text { percent completely retired }\end{array}$ & 6.4 & 12.8 & 19.6 & 29.7 & 42.4 & 50.8 & 62.9 & \\
\hline percent partially retired & 11.9 & 18.6 & 24.8 & 33.5 & 37.8 & 36.7 & 29.9 & 66.9 \\
\hline percent not retired & 81.7 & 68.6 & 55.6 & 36.8 & 19.8 & 12.5 & 7.2 & \\
\hline
\end{tabular}

Sample size 2231. Based on model with parameter estimates shown in Table 3. 
Table 16

Retirement Outcomes: No Constraints on Partial Retirement vs. Current Restrictions

(Numbers reported are in percentages)

\begin{tabular}{lrrrrrrrr}
\multicolumn{1}{c}{ Age } & \multicolumn{1}{c}{55} & \multicolumn{1}{c}{58} & 60 & 62 & 65 & 67 & $69 \begin{array}{c}\text { Percent into } \\
\text { Partial } \\
\text { Retirement }\end{array}$ \\
& & & & & & & & \\
percent completely retired & -2.4 & -4.7 & -6.9 & -10.5 & -14.1 & -15.3 & -13.8 & \\
percent partially retired & 7.8 & 12.2 & 16.1 & 20.0 & 22.1 & 21.2 & 16.9 & 37.0 \\
percent not retired & -5.4 & -7.5 & -9.2 & -9.5 & -8.0 & -5.9 & -3.1 &
\end{tabular}


Table 17: Retirement Outcomes Under Alternative Systems of Personal Accounts

Program Features (variation from base package)

1. Current law projections of traditional Social Security

Revised Systems with Personal Accounts

2. Base package of personal accounts

3. Total conversion to personal accounts

4. Full annuitization required

5. Annuitization optional, full lump sum withdrawal permitted

\begin{tabular}{|c|c|c|c|}
\hline \multicolumn{3}{|c|}{ Retirement Status at Age 62} & Retirement \\
\hline Not & Partially & Fully & Rate Fror \\
\hline Retired & Retired & Retired & FT Wor \\
\hline 41.9 & 14.3 & 43.8 & \\
\hline 32.8 & 9.6 & 57.6 & \\
\hline 27.9 & 8.9 & 63.2 & \\
\hline 36.7 & 15.0 & 48.3 & \\
\hline 31.2 & 8.5 & 60.3 & \\
\hline
\end{tabular}


Table 18: Wealth by Age Conditional on Both Spouses Living (in 1992 dollars, unadjusted for mortality)

Program Features (variation from base package)

$148305 \quad 155113 \quad 122$

122812

88634

56404

29148

2. Base package of personal accounts

111601

138839

123891

95909

67239

83907

132864

115582

88687

61425

4. Full annuitization required

113228

120313

111607

87957

62797

41430

20545

5. Annuitization optional, full lump sum permitted

111600

140271

124077

96008

67277

37339

18108

19528

Base package $=$ Current law traditional benefits, voluntary, partial ( $4 \%$ of contribution) accounts, prorated traditional benefits, annuitize to family poverty level, joint and $2 / 3$ annuity, required personal accounts subject to earnings test. 
Table 19: Percent Choosing Voluntary Annuities Under Base Package of Personal Accounts

\begin{tabular}{|c|c|c|c|}
\hline $\begin{array}{r}\text { Age Retired From FT } \\
\text { Work }\end{array}$ & No Funds Available & Lump Sum & Voluntary Annuity \\
\hline 50 & 9.0 & 60.9 & 30.1 \\
\hline 51 & 3.9 & 64.9 & 31.2 \\
\hline 52 & 3.9 & 64.2 & 31.9 \\
\hline 53 & 1.1 & 63.3 & 35.6 \\
\hline 54 & 1.5 & 57.3 & 41.2 \\
\hline 55 & 1.6 & 56.5 & 41.8 \\
\hline 56 & 3.0 & 49.5 & 47.5 \\
\hline 57 & 1.6 & 50.4 & 48.1 \\
\hline 58 & 2.7 & 45.5 & 51.8 \\
\hline 59 & 3.0 & 46.7 & 50.2 \\
\hline 60 & 3.2 & 40.1 & 56.7 \\
\hline 61 & 3.8 & 46.4 & 49.8 \\
\hline 62 & 7.2 & 69.7 & 23.1 \\
\hline 63 & 8.3 & 20.5 & 71.1 \\
\hline 64 & 8.9 & 18.8 & 72.3 \\
\hline 65 & 6.5 & 20.6 & 72.8 \\
\hline 66 & 5.5 & 19.9 & 74.6 \\
\hline 67 & 3.0 & 20.6 & 76.4 \\
\hline 68 & 4.6 & 22.0 & 73.4 \\
\hline 69 & 6.2 & 22.7 & 71.1 \\
\hline 70 & 8.8 & 37.0 & 54.2 \\
\hline All & 5.4 & 46.2 & 48.5 \\
\hline
\end{tabular}


Table 20A: Traditional Social Security Benefits Plus Benefit From Personal Accounts by Age of Receipt,

Assuming Husband and Wife are Alive

(Unadjusted for mortality, in 1992 dollars)

Program Features (variation from base package)

1. Current law projections of traditional Social Security $\quad 3679 \quad 16139 \quad 16906 \quad 17059 \quad 17059$

2. Base package of personal accounts

$\begin{array}{lllll}48147 & 18665 & 17444 & 17347 & 17407\end{array}$

3. Total conversion to personal accounts

92830

21791

21432

$21113 \quad 21192$

4. Full annuitization required

$7044 \quad 20978$

21898

22078

22128

5. Annuitization optional, full lump sum withdrawal permitted

52012

18386

17110

16999

17061

Base package $=$ Current law traditional benefits, voluntary, partial ( $4 \%$ of contribution) accounts, prorated traditional benefits, annuitize to family poverty level, joint and $2 / 3$ annuity, required personal accounts subject to earnings test.

Table 20B: Traditional Social Security Benefits Plus Benefit From Personal Accounts by Age of Receipt, Assuming Wife Only Is Alive

(Unadjusted for mortality, in 1992 dollars)

Program Features (variation from base package)

1. Current law projections of traditional Social Security

62

70

75

80

2. Base package of personal accounts

$\begin{array}{rrrrr}1061 & 9546 & 10780 & 10999 & 11061 \\ 45127 & 12400 & 11364 & 11296 & 11367 \\ 89992 & 15091 & 14469 & 14098 & 14166 \\ 3861 & 13304 & 14244 & 14413 & 14461 \\ 49001 & 12237 & 11149 & 11067 & 11140\end{array}$

3. Total conversion to personal accounts

4. Full annuitization required

49001

12237

$11149 \quad 11067$

11140

Base package $=$ Current law traditional benefits, voluntary, partial ( $4 \%$ of contribution) accounts, prorated traditional benefits, annuitize to family poverty level, joint and $2 / 3$ annuity, required personal accounts subject to earnings test. 
Table 21: Taxes and Expected Family Benefits from Social Security and Personal Accounts (In 1992 dollars, adjusted for mortality, but not discounted)

Program Features (variation from base package)

\begin{tabular}{rrrr}
\multicolumn{4}{c}{ Sum Over Lifetime } \\
Social & Personal & \\
Sum & Security & Account & Total \\
Taxes & Benefits & Benefits & Benefits \\
& & & \\
171428 & 328955 & 0 & 328955 \\
169304 & 199878 & 210556 & 410434 \\
167331 & 0 & 574346 & 577009 \\
169886 & 199540 & 251026 & 450566 \\
169151 & 199330 & 207820 & 407150
\end{tabular}

Base package $=$ Current law traditional benefits, voluntary, partial (4\% of contribution) accounts, prorated traditional benefits, annuitize to family poverty level, joint and 2/3 annuity, required personal accounts subject to earnings test. 


\section{Appendix}

Appendix Table 1: Reasons for Deletions of Observations

Total sample individuals

Not specified gender

Not specified marital status

Spouse not interviewed if married

Not a career worker

Ambiguity about whether jobs are ss covered

No FT earnings in ss record or self report

$\begin{array}{rr}\begin{array}{l}\text { Observations } \\ \text { Dropped }\end{array} & \begin{array}{l}\text { Observations } \\ \text { Left }\end{array} \\ & \\ 6785 & 12652 \\ 1578 & 5867 \\ 133 & 4289 \\ 497 & 4156 \\ & 3659 \\ 49 & 3610 \\ 36 & 3574 \\ 31 & 3543 \\ 291 & 3252 \\ 865 & 2387 \\ 156 & 2231\end{array}$


Appendix Table 2: Percent Choosing Lump Sum vs. Voluntary Annuities

\begin{tabular}{|c|c|c|c|}
\hline & $\begin{array}{l}\text { No Funds } \\
\text { Available }\end{array}$ & Lump Sum & $\begin{array}{l}\text { Voluntary } \\
\text { Annuity }\end{array}$ \\
\hline \multicolumn{4}{|l|}{ Program Features (variation from base package) } \\
\hline 1. Current law projections of traditional Social Security & 100.0 & 0.0 & 0.0 \\
\hline \multicolumn{4}{|l|}{ Revised Systems with Personal Accounts } \\
\hline 2. Base package of personal accounts & 5.4 & 46.2 & 48.5 \\
\hline 3. Full annuitization required & 100.0 & 0.0 & 0.0 \\
\hline 4. Annuitization optional, full lump sum withdrawal permitted & 0.6 & 50.1 & 49.3 \\
\hline 5. Total conversion to personal accounts & 4.8 & 45.9 & 49.2 \\
\hline 6. Mandatory personal accounts, using offset accounts & 5.0 & 50.9 & 44.1 \\
\hline 7. Mandatory personal accounts & 4.8 & 46.5 & 48.7 \\
\hline 8. Annuitize to single person poverty level & 7.0 & 45.6 & 47.4 \\
\hline 9. Annuitization up to currently scheduled PIA & 4.8 & 52.9 & 42.4 \\
\hline 10. Single annuities & 4.5 & 63.1 & 32.4 \\
\hline 11. Required personal accounts not subject to earnings test & 5.4 & 45.9 & 48.6 \\
\hline
\end{tabular}

Base package $=$ Current law traditional benefits, voluntary, partial ( $4 \%$ of contribution) accounts, prorated traditional benefits, annuitize to family poverty level, joint and $2 / 3$ annuity, required personal accounts subject to earnings test. 


\section{References}

Anderson, Patricia M., Alan L. Gustman and Thomas L. Steinmeier. 1999. "Trends in Male Labor Force Participation and Retirement: Some Evidence on the Role of Pension and Social Security in the 1970s and 1980s". Journal of Labor Economics 17(4), Part 1: 757-783.

Blau, David M. and Donna B. Gilleskie. 2006. "Health Insurance and Retirement of Married Couples". Journal of Applied Econometrics, in Press, available on line, November, http://www3.interscience.wiley.com/cgi-bin/fulltext/113453619/PDFSTART

Bound, J., T.R. Stinebrickner and T. Waidmann. 2006. "Health, Economic Resources and the Work Decisions of Older Men". Paper presented at NBER Summer Institute on Aging.

Burtless, Gary and Robert Moffitt. 1984. "The Joint Choice of Retirement Age and Postretirement Hours of Work." Journal of Labor Economics 3(2): 209-236.

Cagan, Phillip. 1965. The Effect of Pension Plans on Aggregate Savings. New York: National Bureau of Economic Research.

Coile, Courtney, Peter Diamond, Jonathan Gruber and Alain Jousten. 2002. "Delays in claiming Social Security benefits". Journal of Public Economics 84: 357-385.

Disney, Richard and Sarah Smith. 2002. "The Labor Supply Effects of the Abolition of the Earnings Rule for Older Workers in the United States". The Economic Journal 112: C136C152.

Duffie, Darrell and Kenneth J. Singleton. 1993. Econometrica 61(4): 929-952. Feldstein, Martin and Andrew Samwick. 1992. "Social Security Rules and Marginal Tax Rates". National Tax Journal 45: 1-22.

Even, William E. and David A. Macpherson. 2004. "Do Pensions Impede Phased Retirement?" September, Xeroxed.

Fields, Vivian and Robert Hutchens. 2002. "Regulatory Obstacles to Phased Retirement in the For-Profit Sector". Benefits Quarterly 18(3): 35-41.

French, Eric. 2005. "The Effects of Health, Wealth and Wages on Labor Supply and Retirement Behavior". Review of Economic Studies 72: 395-427.

Friedberg, Leora. 2000. "The Labor Supply Effects of the Social Security Earnings Test." The Review of Economics and Statistics 82 (1): 48-63.

Friedberg, Leora and Anthony Webb. 2003. "Retirement and the Evolution of the Pension Structure". NBER Working Paper 9999.

Gordon, Roger H. and Alan S. Blinder. 1980. "Market Wages, Reservation Wages and Retirement". Journal of Public Economics 14: 277-308.

Greene, William H. 2000. Econometric Analysis, Fourth Edition. Upper Saddle River: Prentice Hall.

Gruber, Jonathan and Peter Orszag. 1999. "What to Do About the Social Security

Earnings Test? Issue Brief. Center for Retirement Research at Boston College. July.

Gustman, Alan L. and Thomas L. Steinmeier. 1983. "Minimum Hours Constraints and Retirement Behavior". Contemporary Policy Issues, a supplement to Economic Inquiry, No. 3 (April): 77-91.

. 1984a. "Partial Retirement and the Analysis of Retirement

Behavior". Industrial and Labor Relations Review 37(3): 403-415.

. 1984b. "Modeling the Retirement Process for Policy Evaluation and

Research". Monthly Labor Review 107(7): 26-33.

1985. "The 1983 Social Security Reforms and Labor Supply

Adjustments of Older Individuals in the Long Run". Journal of Labor Economics 3(2): 237-253. 
584.

. 1986. "A Structural Retirement Model." Econometrica 54(3): 555-

\section{4.}

1999. "Effects of Pensions on Savings: Analysis with Data from the Health and Retirement Study". Carnegie-Rochester Conference Series on Public Policy 50: 271324.

Social Security Bulletin, Perspectives 63(4): 3-17.

. 2000. "Retirement Outcomes In The Health and Retirement Study".

Paper 9404, December.

. 2002. "Retirement and the Stock Market Bubble". NBER Working

. 2004. "Social Security, Pensions and Retirement Behavior Within

the Family". Journal of Applied Econometrics.

. 2005a. "The Social Security Early Retirement Age In A Structural

Model of Retirement and Wealth." Journal of Public Economics 89(2-3): 441-463.

. 2005b. "Retirement Effects of Proposals by the President's

Commission to Strengthen Social Security." National Tax Journal 58(1): 27-49.

. 2005c. "Offsetting the Principal in the New Social Security

Accounts." Tax Notes 107(1): 109-114.

Hurd, Michael D. 1996. "The Effect of Labor Market Rigidities on the Labor Force

Behavior of Older Workers". In David A. Wise, editor. Advances in the Economics of Aging.

Chicago: University of Chicago Press: 11 - 58.

Ibbotson Associates. 2002. Valuation Edition 2002 Yearbook. Chicago: Ibbotson Associates.

Katona, George. 1965. Private Pensions and Individual Savings. Ann Arbor: Survey

Research Center, Institute for Social Research, University of Michigan.

Olson, Janice A. 1999. "Who is "62 Enough"? Identifying Respondents Eligible for

Social Security Early Retirement Benefits in the Health and Retirement Study". Social Security

Bulletin 62(3): 51-56.

Pakes, Ariel and David Pollard. 1989. "Simulation and the Asymptotics of Optimization

Estimators". Econometrica 57(5): 1027-1057.

Penner, Rudolph G., Pamela Perun and C. Eugene Steuerle. 2002. "Legal and

Institutional Impediments to Partial Retirement and Part-Time Work by Older Workers".

$\mathrm{http} / / \mathrm{www}$.urban.org/url.cfm?ID=410587.

President's Commission to Strengthen Social Security. 2001. "Strengthening Social

Security and Creating Personal Wealth for All Americans". Washington, D.C..

http://www.commtostrengthensocsec.gov/reports/Final_report.pdf.

Rust, John and Christopher Phalen. 1997. "How Social Security and Medicare Affect

Retirement”. Econometrica 65(4):781-831.

Samwick, Andrew. 1998. "Discount Rate Heterogeneity and Social Security Reform".

Journal of Development Economics 57: 117-146.

Song, Jae G. 2002. "Evaluating the Effects of the Removal of the Retirement Earnings

Test in 2000". Mimeo. Social Security Administration. November.

Song, Jae G. and Joyce Manchester. 2006. "New Evidence on Earnings and Benefit

Claims Following Changes in the Retirement Earnings Test in 2000". U.S. Social Security

Administration, Office of Policy. ORES Working Paper No. 107, June.

Tran, Bac V.. 2002. "The Effect of the Repeal of the Retirement Earnings Test on the

Labor Supply of Older Workers". Xeorx. University of Maryland at College Park. November. 
Trustees Report. 2003. The 2003 Annual Report of the Board of Trustees of the Old Age Survivors Insurance and Disability Insurance Trust Funds. Washington, D.C..

van der Klaauw, Wilbert and Kenneth I. Wolpin. 2006. "Social Security and the Retirement and Savings Behavior of Low Income Households". Mimeo. 